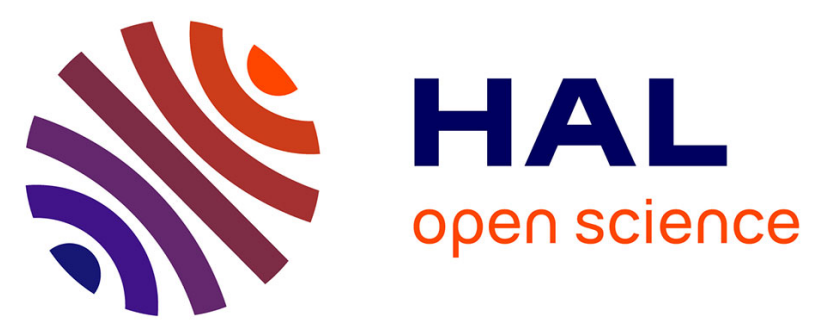

\title{
The Grès Singuliers of the Mont Blanc region (France and Switzerland): stratigraphic response to rifting and crustal necking in the Alpine Tethys
}

Charlotte Ribes, Jean-François Ghienne, Gianreto Manatschal, Nicolas

Dall'asta, Daniel Stockli, Federico Galster, Morgane Gillard, Garry Karner

\section{To cite this version:}

Charlotte Ribes, Jean-François Ghienne, Gianreto Manatschal, Nicolas Dall'asta, Daniel Stockli, et al.. The Grès Singuliers of the Mont Blanc region (France and Switzerland): stratigraphic response to rifting and crustal necking in the Alpine Tethys. International Journal of Earth Sciences, 2020, 109 (7), pp.2325-2352. 10.1007/s00531-020-01902-z . hal-03025585

\section{HAL Id: hal-03025585 https://hal.science/hal-03025585}

Submitted on 26 Nov 2020

HAL is a multi-disciplinary open access archive for the deposit and dissemination of scientific research documents, whether they are published or not. The documents may come from teaching and research institutions in France or abroad, or from public or private research centers.
L'archive ouverte pluridisciplinaire HAL, est destinée au dépôt et à la diffusion de documents scientifiques de niveau recherche, publiés ou non, émanant des établissements d'enseignement et de recherche français ou étrangers, des laboratoires publics ou privés. 


\section{The Grès Singuliers of the Mont Blanc region (France and Switzerland):}

\section{Stratigraphic response to rifting and crustal necking in the Alpine Tethys}

Charlotte Ribes (1*), Jean-François Ghienne (1), Gianreto Manatschal (1), Nicolas Dall'Asta (1), Daniel F. Stockli (2), Federico Galster (2),

Morgane Gillard (3), Garry D. Karner (4).

(1) CNRS-IPGS-EOST, Université de Strasbourg, 1 rue Blessig, Strasbourg, France

(2) Department of Geological Sciences, University of Texas, Austin, Texas 78712, USA

(3) Institut des Sciences de la Terre Paris, Sorbonne Université, Paris, France

(4) ExxonMobil Upstream Integrated Solutions Company, Global Tectonics \& Structure, 22777 Springwoods Village Parkway, Spring, Texas 77389, USA

Present address: C.R., TOTAL S.A., CSTJF avenue Larribau, Pau, France

Corresponding author*: charlotte.ribes@hotmail.fr ;

Phone: 0033 533433306; ORCID: 0000-0003-0528-8149

Keywords: syn-rift, Alpine Tethys margin, Mont Blanc massif, Grès Singuliers, necking

\section{Acknowledgements}

This research was supported by ExxonMobil as part of the CEIBA (Centre of Excellence in Basin Analysis) project. Patricio H. Figueredo and Christopher A. Johnson from ExxonMobil are thanked for valuable discussions on several aspects of this article. We thank H. Masson and J.L Epard for their enthusiasm to share knowledge about the Mont Blanc region. CR thanks S. Triboulet for her wonderful thesis notebooks. J. Tugend, G. Mohn and E. Masini are warmly thanked for fruitful discussions. The seismic section from line GA199-09 has been provided by Geoscience Australia after personal request and is published with the permission of Geoscience Australia. 


\section{Abstract}

The Grès Singuliers unit represents an anomalous occurrence of a siliciclastic-dominated sedimentary system typifying a restricted geographic area around the Mont Blanc massif. Deposited during Early Jurassic rifting, this unit was influenced by the tectonic processes responsible for its development. This contribution integrates and reconciles sedimentological, stratigraphic and tectonic data and discusses the tectono-sedimentary evolution of the Mont Blanc basement and its autochthonous sedimentary cover. Based on depositional facies, a petrographic and detrital zircon provenance analysis, we propose that the Grès Singuliers unit is mainly derived from erosion of the local basement and pre-rift sedimentary cover. Furthermore, recognition of Jurassic cataclasites and black gouges capping the Mont Blanc basement confirms the hypothesis that the Mont Blanc domain formed an extensional core complex. The source to sink relationship between the Mont Blanc detachment system and the Grès Singuliers unit, as well as timing and location within the Alpine rift system, allows us to interpret this unit as the syn-tectonic sedimentary response to crustal necking, responsible for the onset of localized severe crustal/lithospheric thinning in the European margin of the Alpine Tethys rift system. The main result of this study was to show that the exhumation and uplift of basement during crustal/lithospheric necking produced a new source area for clastic sedimentary systems. Therefore, the local occurrence of a siliciclastic unit similar to the Grès Singuliers along passive margins may be symptomatic of necking zones in other rift systems.

\section{INTRODUCTION}

The "Grès Singuliers" were first mentioned by De Saussure (1779). In his "Voyage dans les Alpes", he dedicated a paragraph entitled "Grès remarquables" to these sandstones observed across the Mont Blanc massif. A series of studies followed, mentioning the "Grès remarquables" and renaming them as "Grès Singuliers" (Favre 1867; Ritter 1897; Duparc et al. 1901). Although the term "singuliers" (English: singular/unique), referred initially to the lithofacies interpreted to result from the reworking of the 
underlying polymetamorphic basement, eventually "singuliers" eventually denoted the stratigraphic position that subsequently attracted attention over the next 50 years (i.e. Bonhomme area, e.g. Antoine et al. 1975; Landry 1978; Eltchaninoff and Triboulet 1980; Triboulet 1980; EltchaninoffLancelot et al. 1982). Indeed, the "Grès Singuliers" represents an anomalous occurrence of syn-rift clastic Jurassic sediments that formed within an otherwise carbonate dominated depositional setting at the distal proximal European margin. The uniqueness of the "Grès Singuliers" lies in the fact that this siliciclastic deposit is only observed in a very restricted paleogeographic area of the autochthonous sedimentary cover of the Mont Blanc massif.

The following questions arise from the study of the "Grès Singuliers":

(i) Which type of source to sink system is responsible for the origin of the siliciclastic deposits, and how far is this system singular/unique in rift settings?

(ii) Do the "Grès Singuliers" record a particular time range in rift development?

(iii) Is the position of the "Grès Singuliers" along the margin symptomatic and/or indicative of a particular rift process and/or rift domain?

(iv) Are similar sediments observed elsewhere in the Alpine Tethys and present-day rifted margins?

The study presented here is based on field observations and sampling of the well-exposed remnants of a fossil rifted margin. The study aims to: (i) characterize and understand the spatial and temporal evolution of the syn-rift "Grès Singuliers" sedimentary system that was active in the late Early Jurassic between the proximal and future distal parts of the European passive margin; and (ii) highlight the tectonic significance of such a specific unit emplaced, as it will be substantiated below, during the maximum thinning phase at the transition between crustal stretching and hyper-extension. We will present new sedimentological, structural and provenance data in order to unravel the tectonosedimentary evolution of the Mont Blanc region, which is representative of the European rifted margin (Trümpy 1980; Lemoine and Trümpy 1987). We propose that the Mont Blanc massif is a fossil 
extensional core complex, referred to as the Mont Blanc core complex (MBCC), which was exhumed and uplifted during Early Jurassic rifting. On the basis of our original new model proposed for the Mont Blanc region, we finally discuss general implications of this study for the evaluation of syn-rift megasequences related to major crustal thinning along present-day rifted margins.

\section{GEOLOGICAL SETTING: THE WESTERN HELVETIC DOMAIN}

\section{Nappe stack and palinspastic reconstruction}

During the Jurassic, rifting led to the formation the Alpine Tethys including the Adriatic/Africa and Europe/Iberia margins and intervening Ligurian, Piedmont and Valais proto-oceanic domains (e.g. Debelmas and Lemoine 1970; Lemoine and Trümpy 1987; Schmid et al. 2004). The Alps sensu-stricto are the result of the reactivation and closure of these domains during multiple episodes of convergence with variable kinematics since the Late Cretaceous (Fig. 1; e.g. Stampfli et al. 2002; Schmid et al. 2017 and references therein).

The external parts of the Alpine belt consist of a crystalline basement and its (para)autochthonous sedimentary cover. The former was consolidated during the Hercynian orogeny and late to postorogenic collapse and is exposed in the External Crystalline Massifs (ECM). The late Paleozoic to Cenozoic sedimentary cover (i.e. Helvetic/Dauphinois nappe system; e.g. Trumpy 1963; Masson et al. 1980) extends from the little-deformed Jura Mountains, across the foreland Molasse basin to the foldand-thrust belt. The ECM and associated cover are overthrust along the Penninic Front or Pennine basal thrust by the Helvetic and Penninic nappes derived from more distal parts of the former European margin (Fig. 1; e.g. Schmid and Kissling 2000; Cardello et al. 2019).

The Helvetic nappe system is derived from the Helvetic domain, which is a part of the European proximal margin (e.g. Debelmas and Lemoine 1970; Funk et al. 1987). This domain has been subdivided into paleo-geographic sub-domains that are preserved in the Helvetic and Ultrahelvetic nappes and the underlying Infrahelvetic units. The subdivisions are sometimes arbitrary and in this study we use the subdivision proposed by Escher et al. (1993) and Pfiffner et al. (2010; 2011). The Infrahelvetic 
complex encompasses all units beneath the basal thrust of the Helvetic nappes (Fig. 2). It consists of pre-rift sedimentary and crystalline basement rocks (i.e. Mont Blanc-Aiguilles Rouges and Gastern-Aar ECMs) and autochthonous to para-autochthonous pre-to post-rift Mesozoic and Cenozoic sediments (i.e. Morcles and Doldenhorn nappes, Fig. 2; e.g. Masson et al. 1980; Escher et al. 1993). The Helvetic nappe stack, comprising the Diablerets, Roselette, Gellihorn and Wildhorn nappes, includes allochthonous sediments that derive from a more distal part of the European proximal margin. These units were thrust during the Cenozoic toward the northwest along a basal thrust fault over distances of several tens of kilometres (i.e. Diablerets thrust or basal Helvetic thrust, Fig. 2; e.g. Masson et al. 1980; Pfiffner 1993; Crespo-Blanc et al. 1995). Ultra-Helvetic nappes occur either underneath the Diablerets basal thrust of the Helvetic nappes or above the Helvetic nappes and were initially deposited on the most distal southeasternmost part of the European proximal margin (Fig. 2; e.g. Badoux 1963; Jeanbourquin and Goy-Eggenberger 1991; Escher et al. 1993; Pfiffner 2011).

Palinspastic reconstructions through the Helvetic domain proposed in the literature (Fig.2C; e.g. Trümpy 1980; Burkhard 1988; Wildi et al. 1989; Steck et al. 1999; Pfiffner 2011) generally indicate that the main units described in this study, from the Croix du Bonhomme and Swiss Val Ferret area (Fig. 2C), belong to the autochthonous sedimentary cover of the Mont-Blanc massif (Fig. 2D). The "Grès Singuliers" however also occurs in the para-autochthonous nappes of the Infrahelvetic complex and more specifically in the Doldenhorn and Morcles nappes (Fig. 2A).

\section{Pre-rift sediments and crystalline basement rocks}

The Mont Blanc and Aiguilles Rouges crystalline massifs consist of a pre-Mesozoic polymetamorphic basement intruded by Variscan S- and I-type granitoids (e.g. Finger and Steyrer 1990; Von Raumer and Bussy 2004). Examples are the Vallorcine Granite in the Aiguilles Rouges massif (306 $\pm 1.5 \mathrm{Ma}$, Bussy et al. 2000), the Mont Blanc Granite (303 \pm 2 Ma, Bussy and Von Raumer 1993) as well as the Variscan rhyolites of the Mont Blanc massif (307 \pm 2 Ma, Capuzzo and Bussy 2000). The emplacement depth of the Mont Blanc granite has been estimated at 4 to $14 \mathrm{~km}$ (1 to $3.8 \mathrm{kbar}$; Marshall et al. 1997). The 
rhyolitic unit was emplaced at shallower crustal levels (Von Raumer and Bussy 2004) and display textures ranging from leucocratic granites to porphyritic rhyolites (e.g. Marshall et al. 1997). The contact between the rhyolitic unit and the Mont Blanc Granite remains ambiguous (e.g. Capuzzo and Bussy 2000).

The Aiguilles Rouges massif includes Late Carboniferous siliciclastic sediments preserved in mildly inverted grabens (e.g. Von Raumer et al. 1993; Capuzzo and Bussy 2000). These pluri-kilometric thick basins, including the Pormenaz and Salvan-Dorénaz basins, consist of fluvial, alluvial fan and volcanic deposits (e.g. Capuzzo and Wetzel 2004).

The Triassic succession (or very locally Permian strata) unconformably covers the Carboniferous basins as well as the polymetamorphic and granitic basement rocks (e.g. Amberger 1959; Epard 1990; Wizevich et al. 2019). The succession starts with several meters of fluvial to shallow-marine sandstones overlain by vari-coloured pelites constituting the Middle to Upper Triassic Vieux Emosson Fm (Fig. 3; e.g. Epard 1990; Avanzini and Cavin 2009; Wizevich et al. 2019). Up section, the Arandellys Fm consists of dolostones locally interbedded with evaporites and overlain by the Besoëns Fm, characterized by bioclastic sandy limestones and sandstones interbedded with dark marls and shales (Fig. 3, e.g. Epard 1990). This typical succession can be observed in the Emosson area and within the Morcles nappe (Fig. 2A, e.g. Amberger 1959; Epard 1989; Wizevich et al. 2019). However, along the Mont Blanc massif, the pre-rift Triassic (and Early Jurassic) deposits are either lacking or represented by reduced successions (a few tens of meters locally). We will discuss whether this is due to non-deposition, erosion or if they have been tectonically removed.

Furthermore, the basement-cover relationships between the Mont Blanc basement and its sedimentary cover remain in places still debated in the literature. On the eastern, Italian side of the Mont Blanc massif, the basement-cover contact in the Italian Val Ferret and Val Veni (Fig. 2A) has been interpreted either as: (i) the Mont Blanc back-thrust and described as a series of steeply NW-dipping thrust faults bringing the Mont Blanc granite on top of overturned Jurassic sediments (e.g. Guermani 
and Pennacchioni 1998; Leloup et al. 2005; Egli and Mancktelow 2013), or (ii) as the Evêque back-fold, locally overturning a primary basement-cover contact (e.g. Escher et al. 1997; Steck et al. 2001). To the south-west of the Mont Blanc massif, the basement-cover contact (i.e. Col de la Forclaz, Col de Balme, Col du Mont Lachat, Col du Tricot; Fig. 2A) is interpreted as an overturned stratigraphic contact, either involving a tectonic thrust between the Mont Blanc basement and the Mesozoic sediments (e.g. Eltchaninoff-Lancelot et al. 1982; Leloup et al. 2005; Egli and Mancktelow 2013) or without any tectonic thrust and thus preserving a primary basement-cover contact (e.g. Epard 1986). In this paper, we will describe new basement-cover contact relationships across the Mont Blanc massif from the Croix du Bonhomme area and the Swiss Val Ferret (Fig. 2).

\section{Alpine Tethys rifting and associated syn-rift stratigraphy}

The syn-rift megasequence (sensu Hubbard 1988) of the Alpine Tethys rifted margins developed from latest Triassic to Middle Jurassic (e.g. Lemoine and Trümpy 1987). In the study area, the early phase of rifting, Early Jurassic, is characterized by the development of numerous fault-bounded half-grabens, which are well preserved along the proximal European margin such as in the Dauphiné domain (i.e. Bourg d'Oisans, La Mure, Taillefer, e.g. Lemoine et al. 1986; Chevalier 2002) and in the Helvetic domain (i.e. Morcles and Doldenhorn nappes, e.g. Lemoine et al. 1986; Burkhard 1988; Epard 1990). The halfgrabens in the Morcles and Doldenhorn nappes are filled by Hettangian to Sinemurian shales, marls and limestones (i.e. Tierces Fm, Fig. 3; Epard 1989).

During the Late Sinemurian-Toarcian, the western Helvetic domain records the deposition of two types of facies (Trümpy 1971): the siliciclastic "Helvetic facies" and the marly "Dauphinois facies". The siliciclastic "Helvetic facies" are dominated by sandstones deposited above or near the ECMs, i.e. belonging, regarding the study area, to the autochthonous cover of the Mont Blanc massif and paraautochthonous cover of the Aar massif (Doldenhorn nappe; e.g. Trümpy 1971; Loup 1991). These siliciclastic facies, which include the so-called "Grès Singuliers" in France, are also referred to as the "Lotharingien" and "Domérien" sandstone units on the Swiss part of the Mont Blanc massif (i.e. 
Catogne, Fig 2; e.g. Grasmück 1961) and in the Doldenhorn nappe and Aar massif (i.e. Torrenthorn; e.g. Loup 1991). Based on the distribution of the siliciclastic Helvetic facies above and around the ECM without any external clastic sources to produce the siliciclastic facies other than the ECM by themselves, Trümpy (1971) proposed that the Mont Blanc and Aar domains were partially emerged at that time, corresponding to "islands" during the Early Jurassic ("île du Mont Blanc" and "presqu'île du Bietschhorn", respectively). For the sake of simplicity, we will use in this study the term "Grès Singuliers unit" for all the Early-Middle Jurassic siliciclastic deposits observed in the overall Mont Blanc region, then encompassing both the French Grès Singuliers Fm sensu stricto and the Swiss "Lotharingien" and "Domérien" sandstone units, as well as similar subordinate clastic horizons from the Italian side of the Mont Blanc massif. The marly "Dauphinois facies", dominated by limestone and marls, are deposited in the surrounding areas including the Morcles, Helvetic and Ultrahelvetic nappes (Figs. $2 \mathrm{C}$ and 3). Locally in the Doldenhorn and Morcles nappes, the siliciclastic "Helvetic facies" is found interbedded with the marly "Dauphinois facies" (e.g. Saillon in Fig. 2); the clastic input progressively disappearing more distally in the Helvetic nappes (Fig. 2)

In the Helvetic domain, the late Early to Middle Jurassic time is characterized by the deposition of dark marls and limestone of the Toarcian Monts Rossets Fm overlain by the black lime-free Aalenian pelites of the Dugny Fm (Fig. 3; e.g. Epard 1989). Based on the recent understanding of the Southern and Northern Adriatic margin, the corresponding time interval precisely records the focusing of extension processes linked to the major crustal thinning stage of the continental crust that led to the formation of the distal European and distal Adriatic margins (i.e. Ultra-Helvetic, Lower Penninic and Lower Austroalpine nappes; e.g. Lemoine and Trümpy 1987; Berra et al. 2009; Masini et al. 2013; Ribes et al. 2019b).

The final stage of rifting, marked by the exhumation of mantle and onset of magma activity, occurred in the Ligurian, Piedmont and Valais domains (e.g. Lemoine and Trümpy 1987; Liati et al. 2005; 
Manatschal and Müntener 2009; Li et al. 2013). Remnants of these domains are preserved in the Lower and Upper Penninic nappes (e.g. Desmurs et al. 2001; Manatschal et al. 2006; Beltrando et al. 2012; Ribes et al. 2019c). Mantle exhumation was concomitant with the deposition of radiolarian cherts dated from the late Middle to early Late Jurassic (e.g. Bill et al. 2001; Principi et al. 2004; Baumgartner 2013; Ribes et al. 2019b).

By comparison with the northern Adriatic margin, the deposition time of the Grès Singuliers unit (i.e. late Early to Middle Jurassic) corresponds to the moment when fault activity stops in the proximal margin and deformation starts to focalize in an area that corresponds to the futur distal margin (i.e. necking system tract sensu Ribes et al. 2019b). Furthermore, the Mont Blanc massif, where the Grès Singuliers unit is observed, is positioned at the transition between a non- to weakly-thinned continental crust to thinned continental crust (Fig. 1D; e.g. Stampfli et al. 2002; Mohn et al. 2014). Thus, the location as well as the timing relative to the margin evolution indicated that the Grès Singuliers unit should bears key information about the rift evolution of the Alpine Tethys, in particular regarding the necking system tract as defined by Ribes et al. (2019b).

\section{BASEMENT-COVER RELATIONSHIPS ACROSS THE MONT BLANC MASSIF}

\section{Basement and Pre-rift stratigraphy}

Where the sedimentary autochthonous cover of the Mont Blanc ECM is preserved, the underlying basement consists of three distinct units: Variscan metamorphic rocks comprising orthogneisses and paragneisses, the Carboniferous Mont Blanc granite and a rhyolitic/porphyritic unit (Fig. 2; e.g.Von Raumer and Bussy 2004). The sedimentary interval between the Mont Blanc top basement and the Grès Singuliers unit shows a variable and reduced stratigraphic succession ranging in thickness from several tens to a few meters (Fig. 6A). This situation is distinctive if compared with facies and great thicknesses of the relatively uniform sedimentary cover of the Morcles nappe (e.g. Epard 1990) and the autochthonous sedimentary cover of the Aiguilles rouges (i.e. Emosson; Amberger 1959). 
The sediments comprised between the Mont Blanc top basement and the Grès Singuliers unit are made up of Middle Triassic sandstones (i.e. Vieux Emosson Fm, Epard 1989; Wizevich et al. 2019) overlain by Late Triassic light brown to yellowish dolostones passing upward to dark alternating dolostones, limestones and marls (i.e. Arandellys Fm, Eltchaninoff-Lancelot 1980; Epard 1989). The last Triassic deposit is characterized by thin sandstones and shales (i.e. Besoëns Fm, Eltchaninoff-Lancelot 1980; Epard 1989). Below the unconformable Grès Singuliers unit, Hettangian to early Sinemurian marls and limestones are observed (i.e. Tierces Fm, Landry 1976; Eltchaninoff-Lancelot 1980).

\section{Deformation structures}

\section{Croix du Bonhomme and Swiss Val Ferret (main study area)}

\section{- Top basement}

In the Bonhomme and Swiss Val Ferret area (Fig. 4), the top basement shows a characteristic fault zonation with from base to top: (i) an undeformed host rock (i.e. gneiss or rhyolitic/porphyritic granite), (ii) a brittle damage zone with cataclasites, and (iii) a core zone that consists of black gouges.

The cataclasites correspond to brittle deformed basement, which in places shows a progressive change upsection from a fractured host rock to a clast-supported cataclasite. Clasts are generally angular, showing jigsaw textures at the base, yet they develop into more rounded clasts up section (Fig. 5B, C and $D$ ). The primary material derived from the gneissic host rock consists of rock fragments made of quartz and feldspars. Quartz occurs in the cataclasite as angular grains forming, together with feldspar, a clast supported framework intersected by micro-fracturing (i.e. intra- and transgranular cracks) and quartz veins (Fig. 5G). Quartz has embayments and feldspars show evidence of chemical weathering. Albitization is observed but not common. The matrix between the clasts is made of crushed finegrained host rocks (Fig. 5G).

The gouges are well foliated, matrix-supported black rocks with less than $30 \%$ fragments including mmto $\mathrm{dm}$-sized clasts derived from the underlying basement, cataclasites, and more rarely "Triassic" dolostones and quartzites from the hanging wall (Fig. 5B, D and E). The black gouges occur along a 
centimetre- to decimetre-thick core zone that tops the cataclasite (Fig. 5B and D). The contact between the black gouge and cataclasites is sharp and injection structures of the black gouge into the underlying cataclasites are found in places (Fig. 5D and F). With decreasing size, polymineralic litho-clasts become less abundant and the proportion of monomineralic clasts increases. Monomineralic clasts consist of sub-rounded quartz and remnants of feldspar grains embedded in a phyllosilicate-rich matrix. Common micro-structures in the quartz are micro-cracks and fractures. Elongated fragments show a strong preferred orientation and $\mathrm{S} \pm \mathrm{C}$ type fabrics with the slip plane parallel to the fault-zone boundary are common (Fig. 5G). The black gouges correspond to the main zone of displacement and define a fault plane separating footwall and hanging-wall rocks (e.g.Chester and Logan 1986; Scholz 1987).

In the Bonhomme area, the top basement is characterized by cataclasites and locally preserved black gouges that look to be paraconformably overlain by a discontinuous sedimentary cover made up of Triassic and Lower Jurassic strata unconformably covered by the Grès Singuliers unit (Fig. 4B). In the Swiss Val Ferret area, from the Combe des Fonds to Saleinaz (Fig. 4C), the rhyolitic/porphyritic top basement is characterized by cataclasites overlain by a clast-supported conglomerates with pebbles to cobble-sized monomictic rhyolitic elements, referred to as the Amône conglomerate and attributed by Grasmück (1961) to the Aalenian. This top basement forms a corrugated (undulating) surface with corrugation wavelength of several meters. Here, intervening grooves are filled by the Amône conglomerate sealed by Aalenian dark shales (Fig. 5A and B). Toward the north, the top basement surface is overlain by discontinuous Triassic and Lower Jurassic stratigraphy reminiscent of the organisation symmetrically documented to the south in the Bonhomme area (Fig. 4C).

\section{- Sedimentary cover}

Where a Triassic to Early Jurassic succession is preserved above the top basement (i.e. Croix du Bonhomme and Swiss Val Ferret, Fig 4), it is strongly dismembered by pervasive stratal disruption resulting from extension parallel to the layering, which cannot be observed in the underlying basement rocks or Grès Singuliers unit and overlying strata (Fig. 6). 
At the outcrop scale, extensional ramps cut the dolostone and limestone beds and flatten upwards and downwards as decollements in the marly or shaly intervals. Beds, or groups of beds, are thus truncated in lens-shaped, fault-bounded blocks of centimetric to decametric scale (Fig. 6B, C and D). A complete transition from massive well-bedded dolostone and limestone layers to monomictic breccialike layers has been observed both in Bonhomme and Swiss Val Ferret areas. The dolostone and limestone layers are locally affected by intense silica-rich veining and fracturing, and subsidiary Ca-rich veins, that progressively merge, and the massive rocks appear to be broken into numerous centimeterto meter-sized clasts (Fig. 6B, D and E). Because of the geometry of the deformation and of the monogenetic constitution of the succession, the breccia is interpreted to be of tectonic rather than sedimentary origin (e.g. Labaume 1987). Locally the Triassic to Lower Jurassic succession is affected by a complex array of downward-tapering sedimentary dykes and sills penetrating a few meters and filled by conglomerate and/or sand originating from the basal Grès Singuliers unit.

\section{Italian Val Ferret and Col de Tricot}

From the southeastern Italian border of the Mont Blanc massif, along La Brenva Stream and at Pra-Sec in Val Veni, Elter and Elter (1964), Guermani and Pennacchioni (1998) and Leloup et al. (2005) among others mentioned at the top basement a transition from an undeformed granite to a cataclasite. Guermani (1998) also described in association with the cataclasite a dark thin layered rock with a strong foliation parallel to the shear zone boundary with clasts of rounded cataclastic granite, in which the matrix consists of fine-grained phyllosilicate and albite. By analogy with the Croix du Bonhomme observations, it is likely that these dark thin layered rocks correspond to the black gouges described in the previous section. The top basement is covered by a few meters thick succession displaying undeformed and undated sandstone beds overlain by a single limestone bed and lime-free dark shales. The latter was interpreted as representative of a thin autochthonous cover below the Diablerets thrust and the overlying Helvetic nappes (e.g. Antoine et al. 1975; Aviolat 1991; Mamin 1992). Shear criteria in the cataclasites and black gouges display a top to the SE (dip slip) (e.g. Leloup et al. 2005, Guermani, 

compatible with a top to the SE detachment system.

In the western part of the Mont Blanc massif, in the Col de Tricot area, Epard (1986) described at the top basement a highly deformed gneiss associated with dark thin layers consisting of phyllosilicate-rich matrix (mainly sericite) with elongated-clasts of polygonal quartz. This tectonized top basement is however overlain by a discontinuous sedimentary cover made up of Triassic and Lower Jurassic sediments, which is considered as para-autochtonous by Epard (1986). These observations are similar to our observations from the Croix du Bonhomme, Swiss Val Ferret and from the Italian Val Ferret (Guermani and Pennacchioni 1998) where top basement is characterized by cataclastic fabrics overprinting either a rhyolitic/porphyritic granite or gneissic host rock, and the occurrence of diagnostic thin foliated dark rocks that we interpret as black gouges.

\section{Rift-related detachment faults: Mont Blanc detachment system?}

Although basement-sediment contacts along the Mont Blanc are generally interpreted as Alpine thrusts (i.e. Mont Blanc back-thrust; e.g. Leloup et al. 2005; Egli and Mancktelow 2013), we argue that these contacts that are subparallel to the overlying sediments, could be alternatively interpreted as former Jurassic extensional detachment faults that were essentially preserved and only reactivated locally as reverse faults during Alpine convergence.

327 Cataclasites and gouges, which appear paraconformable with the pre-rift stratigraphy and/or the overlying sediments, are arguably linked to extensional detachment systems. These structures and the rocks are reminiscent of the low angle detachment faults and associated products described initially by Froitzheim (1990) from the Err nappe in SE Switzerland and representing rift related detachment systems (e.g. Manatschal 1999; Masini et al. 2012; Epin and Manatschal 2018). The top basement records systematically a brittle overprint, with in places the reworking of footwallderived clasts and occasionally Triassic dolostone, sealed by undeformed Aalenian conglomerates and/or Aalenian dark shales. The variable and reduced Triassic to Lower Jurassic sedimentary cover 
overlying the exhumed basement forms kilometric-scale slices. Deformation in these slices, characterised by a pervasive extensional delamination, which is not observed in the underlying basement or in the Grès Singuliers unit, is interpreted as related to the exhumation of the underlying crustal detachment during deposition of the Grès Singuliers unit. These slices of sedimentary layers predating the Grès Singuliers unit are interpreted as slivers of pre-rift/early syn-rift displaced along detachment systems. The observation that the Mont Blanc is locally capped by brittle fault rocks belonging to a pre-Alpine Jurassic detachments (for discussion see below), allows us to introduce the potential existence of the Mont Blanc detachment system. The mapping of remnants of this supposed former Jurassic detachment system in the Mont Blanc massif suggests that exhumation of the detachment footwall to the seafloor occurred throughout the Mont Blanc domain, except for the areas where the detachment was hidden by slivers of pre-rift preserved along detachment systems.

The description of the Mont Blanc top basement and associated sedimentary cover thus shows strong similarities with other rift-related detachment faults observed in remnants of the former distal Alpine Tethys rifted margin. Preserved and exposed extensional detachment faults and extensional allochthons or pre-rift slivers in the Alps were first described by Froitzheim (1990) and then recognized in several places such as the Tasna nappe (e.g. Froitzheim and Rubatto 1998; Manatschal et al. 2006; Ribes et al. 2019c), the Austroalpines nappes (e.g. Mohn et al. 2012; Incerpi et al. 2017), and in the Pyrenees (e.g. Clerc et al. 2016; Lagabrielle et al. 2016). Classically, these rift-related detachment faults are formed by tens of meter thick damage zones constituted of characteristic green cataclasites and a core zone made of black indurated fault gouges (e.g. Manatschal 1999; Manatschal et al. 2000; Mohn et al. 2011; Masini et al. 2012), which are definitely similar to what has been observed at the top of the Mont Blanc basement.

\section{THE GRÈS SINGULIERS UNIT}


In the Croix du Bonhomme area, the Grès Singuliers unit rests on the early Sinemurian Tierces Fm (Landry 1976; Eltchaninoff-Lancelot 1980) at the Rocher du Bonhomme (Fig. 8) but unconformably overlies Triassic deposits immediately toward to northeast (Fig. 8). The top of the Grès Singuliers unit is overlain by lime-free dark shales attributed to the Aalenian Dugny Fm (Fig. 8; Epard 1990). In the Swiss Val Ferret area, the Grès Singuliers unit conformably covers early Sinemurian limestones and marls and unconformably overlies Triassic deposits and, southward, basement rocks (Fig. 9; Grasmück 1961). At the top of the Grès Singuliers unit, a regional onlap is inferred considering the overlying Toarcian Monts Rossets Fm in the basinal part (Trümpy 1951) and the Aalenian Dugny Fm toward the south overlying directly the Aalenian Amône conglomerates (Fig. 9; Grasmück 1961). In the Val Veni and Italian Val Ferret, the sedimentary veneer is interpreted as a lateral equivalent of the Amône section in the Swiss Val Ferret and section E of the Croix du Bonhomme area (Fig. 8) with the quartz arenite attributed to the Grès Singuliers unit, the limestones and the overlying lime-free dark shales attributed to the Toarcian - Aalenian Monts Rossets and Dugny Fms, respectively.

The facies distribution around the Mont Blanc massif suggests lateral variations related to the distance from a siliciclastic source with lag deposit and coarse-grained facies evolving basinward into finergrained facies with an increasing contribution of carbonate supply (Fig. 9; e.g. Loup 1991). The thickness of this formation thickens progressively from 0 (i.e. Amône) to $150 \mathrm{~m}$ in the basinal zone toward the south of the Val Ferret (i.e. Saillon, Fig. 9) and from $40 \mathrm{~m}$ in the south of the Bonhomme area (Fig. 8) to a few tens of meters toward the north to finally be restricted to a few decimetre thick veneer resting directly above the top basement.

\section{Facies analysis}

The Grès Singuliers unit is a siliciclastic-dominated sedimentary system, including clast-supported conglomerates, lithic to quartz arenites and sandy limestones that unconformably overlie either the 

paragraph, we detail the facies of the Grès Singuliers unit in the Croix du Bonhomme type area and then briefly describe those of the Swiss Val Ferret area.

\section{Croix du Bonhomme}

The Grès Singuliers unit ranges from 8 to $35 \mathrm{~m}$ in thickness and consists of light yellowish conglomerates and sandstones (Fig. 7). The succession is subdivided in two parts: a poorly stratified lower subunit including conglomerates, and an upper subunit made of cross-stratified sandstones.

The lower subunit rests unconformably on an erosional surface truncating the Lower Jurassic to Middle Triassic strata. A complex of sedimentary dykes and sills including conglomerate and sandstone similar to those of the lowermost Grès Singuliers unit penetrates few meters into the underlying strata. The Grès Singuliers unit starts with meter-thick structureless, poorly graded, polymictic conglomerates composed of sub-rounded centimeter-to decimeter-sized clasts (Fig. 7A). The conglomeratic facies are overlain, above a sharp grain-size break, by a poorly sorted coarse- to medium-grained sandstone with faint primary lamination, possibly emphasised in places by subhorizontal dewatering structures. Normally graded beds with undulating lamination, $20-40 \mathrm{~cm}$ thick, are occasionally observed. They show ripple cross-lamination reworking the bed top, which are capped by mm-thick fine-grained intervals (Fig. 7C). A few Belemnite rostra and Gryphea sp have been observed. A recurrence of conglomerates is observed upward, which locally shows climbing-dune cross-stratification. Clast lithologies in both the conglomerate intervals are dominated by crystalline rocks, $90 \%$ originating from the Mont Blanc type granite and $10 \%$ from the adjacent gneissic basement, with subordinate occurrence of limestones and dolostones and rare quartzites (e.g. Eltchaninoff-Lancelot 1980). Numerous granitic clasts (80\%), generally rounded to well rounded, are entirely cataclastic and resemble the deformed basement granite observed along Val Veni. Carbonate clasts are sub-rounded to angular. 
The upper subunit of the Grès Singuliers unit consists of sharp-based, 1-2 m thick, medium-grained

413 sandstone beds that generally display fining-up trends, including small gravel lags near their base (Fig.

7). Sets of tangential oblique lamination are observed either isolated or amalgamated and then forming trough cross-stratified beds (Fig. 7B). A few intercalations, less than one meter thick, consist of distinctively well-sorted sandstones showing a finely defined, oblique to subhorizontal lamination, which may display thickening to fining rhythmic pattern in laminae thickness (Fig. 7E). The middle segment of the upper Grès Singuliers subunit is typified by sandstone beds showing networks of crosscutting, $10-30 \mathrm{~cm}$ deep, $1-5 \mathrm{~cm}$ thick sand intrusions. Whether they originated from the overlying or underlying bed remains ambiguous. Intrusions are arranged in nested polygonal to rectangular cells, yet a preferential north-south orientation has been noticed (Fig. 7D). The uppermost Grès Singuliers unit is a distinctive up to $4 \mathrm{~m}$ thick sandstone body that shows large-scale clinoformal master beds downlapping toward the SW, and that pinches out in the opposite direction (Fig. 7F). They are truncated by an individual coarse-grained sandstone bed showing in places bioturbation in the form of U-shaped burrows (probably Diplocraterion and Arenicolites) and undefined tracks. Paleocurrent directions using mainly cross-bedded foreset dips were measured throughout the upper unit of the Grès Singuliers unit, yielding a range of paleoflow orientations from $\mathrm{N} 280^{\circ}$ to $\mathrm{N} 160^{\circ}$ with a mean vector toward $\mathrm{N}^{2} 30^{\circ}(\mathrm{SW})$, i.e., more or less parallel with the clinoforms observed near the top of the unit.

In thin section, the sandstone facies of the Grès Singuliers evolves from base to top and are classified as lithic arenite to quartz arenite, respectively, according to the classification of Pettijohn et al. (2012). The basal sandstones display locally a carbonate matrix-supported fabric but most of the Grès Singuliers have a grain-supported fabric with $200 \mu \mathrm{m}$ to $1 \mathrm{~mm}$ sized, angular to surrounded grains (mean $0,37 \mathrm{~mm}$ ). Detrital grains are principally composed of monocrystalline and polycrystalline quartz (80-90\%), weathered feldspar, cataclastic granitic grains and rare crushed $\mathrm{mm}$-size clast of fine-grained material (Fig. 7G). 
The lower subunit is interpreted as deposits dominated by shallow water density-flow processes. The carbonate matrix and the fossils observed in the lower subunit are interpreted as originated from the reworking of the Hettangian-Early Sinemurian limestones (i.e. Tierces Fm), probably still poorly lithified during the deposition of the Grès Singuliers unit. Graded beds with rippled tops are interpreted as high-density turbidites reworked by subsequent low-density turbidity flow processes (e.g. Talling et al. 2012). The general lack of mudstone might be explained by buoyant plumes that kept the mud in suspension and carried it farther seaward out of the depositional area of the Grès Singuliers unit.

The downward-tapering clastic intrusions in the pre-Grès Singuliers strata have been probably triggered by syn-sedimentary tectonic activity along the underlying detachment system (e.g. Jolly and Lonergan 2002).

The upper subunit is interpreted as deposited under the influence of tidal currents in mud-free siliciclastic subtidal systems (e.g. Longhitano et al. 2012). Cyclic laminae thickness changes suggest the record of neap-spring tidal cycles (e.g. Kreisa and Moila 1986). The trough cross-bedding are interpreted to represent the migration of sinuous-crested dunes during dominant tidal flow and the clinoforms are interpreted as tidal bars (e.g. Olariu et al. 2012; Reynaud and Dalrymple 2012). The small sandstone dykes relate to subaqueous crack/fractures related to loading and compaction, or may be caused by seismic activity as suggested by their preferred N-S orientation. Similar features are reported in tectonically active setting (e.g. Tanner 1998; Sharp et al. 2000; Carr et al. 2003; McMahon et al. 2017).

In this context, the relatively uniform paleocurrents noted in the Grès Singuliers upper subunit are interpreted to reflect tidal currents with a prevailing transport direction toward the SW, which is nearly parallel to the SW-NE elongated Mont Blanc massif.

Furthermore, the outline of monocrystalline quartz grains commonly displays embayments and feldspars show evidence of chemical weathering, both the features being observed in the underlying basement. Crushed fine-grained grains are reminiscent of fragments originating from the 
phyllosilicate-rich black gouges while cataclastic granitic grains may directly derived from the reworking of an exhumed top basement.

\section{Swiss Val Ferret}

From the Combe des Fonds to Saleinaz, the Grès Singuliers unit corresponds to a thin $(0-4 \mathrm{~m})$ sandstone veener that is overlying a cataclastic rhyolitic-porphyritic top basement. In Combe des Fonds, no sandstone was deposited. Instead, a distinctive conglomeratic horizon is observed. It consists in a monomictic rhyolitic-porphyritic conglomerate ("Amône conglomerate", Grasmück 1961; Duparc and Pearce 1989). Clast-supported pebbles to cobbles are sub-rounded to well-rounded rhyoliticporphyritic clasts, while the matrix is made up of coarse-grained sand. This conglomerate horizon is interpreted as a lag deposit formed by the reworking of a cataclasite derived from the nearby underlying deformed top basement. Cataclasis at the top basement, sealed by non-deformed conglomerates, indicates the that the basement-cover contact is a former detachment fault (see above), the footwall of which became available to winnowing and/or sedimentation. Historically, this facies was indeed considered as "beach facies" due to the roundness of the clasts (Trümpy 1954; Grasmück 1961). A though part of the roundness might also have been acquired during deformation processes (e.g.Chester and Logan 1986; Scholz 1987). As no gouge is observed there, it can be suspected that winnowing involved wave action and thus that initially shallow environments deepen afterwards.

At Saleinaz (Fig. 4C), the rhyolitic top basement is overlain by a 3-4 meters thick interval of Grès Singuliers that are coarse-grained and poorly sorted. Poorly defined trough cross-stratification, rippled bed tops and diplocraterion burrows have been observed. These characteristics are reminiscent of the tidally-influenced upper subunit of Grès Singuliers from the Bonhomme area. Here, in a shaly facies immediately above the sandstones, Grasmück (1961) found an ammonite (Ludwigia murchisonae) that indicates an Aalenian age. 
Toward the north, in the Catogne area (Fig. 2), the Grès Singuliers unit dramatically thickens (Fig. 9). Here, an up to $100 \mathrm{~m}$ thick sandstone-dominated unit presents a very similar succession to the one observed in the Bonhomme area, including a lower conglomeratic unit and a tidally-dominated upper segment, within which tidal bars have also been identified by Loup (1991) and Grasmück (1961). The Grès Singuliers unit here also display in places carbonate matrix-supported fabrics with $250 \mu \mathrm{m}$ to 3 $\mathrm{mm}$ sized, angular to surrounded grains (Loup 1991). Detrital grains are composed of $70 \%$ of monocrystalline and polycrystalline quartz, and nearly equal proportions of dolomicrites, altered Kfeldspars, and fresh plagioclase and porphyric microgranite (Loup 1991).

In the Saillon section, which is lateral or distal with respect to Catogne (Fig. 2C), two sandy units (Lotharingien \& Domerien) have been traditionally distinguished, which are arguably parallelized with the basal and upper subunits of the Grès Singuliers in the Croix du Bonhomme area, yet showing an overall greater thickness (up to $150 \mathrm{~m}$ ) and a greater contribution of the carbonate matrix. They are made up of well-sorted fine- to coarse-grained sandstones, composed of $90 \%$ of quartz in a carbonate matrix (grain size $100 \mu \mathrm{m}$ to $3 \mathrm{~mm}$; Loup 1991). An intervening finer grained package has been deposited. It consists of alternating sandy limestone and wackstone to packstone limestones with abundant echinoderm debris, bivalves and sponge spicules and detrital grains represented by quartz and dolostone (Loup 1991). In spite of this distinctive fine-grained unit, overall stratigraphic patterns, depositional facies and ages of the Swiss Grès Singuliers unit are largely comparable to those of their French counterpart, the corresponding depositional bodies being deposited over the NE and SW tip of the Mont Blanc ECM, respectively.

\section{GRÈS SINGULIERS PROVENANCE : Detrital zircon analysis}

Detrital zircons (DZ) were separated from sandstone of the Grès Singuliers unit (samples EC16 and EC17) and Triassic quartzite (EC20) from the Bonhomme area, the Grès Singuliers unit in Catogne area (samples CR-MB-1B and CR-MB-1A) and Permo-Triassic sediments in the Sion-Courmayeur nappe 
515 (Sample EC23; Fig. 2). From each sample 140-160 detrital zircon (DZ) grains were randomly chosen and

516 analysed for U-Pb geochronology by laser ablation inductively coupled plasma mass spectrometry (LA-

517 ICPMS). U-Pb analyses were completed using a Photon Machines Analyte G2 excimer laser with a

518 HeLex 2-volume sample cell and a Thermo Scientific Element2 ICP-MS, following procedures outlined

519 Hart et al. (2016). GJ1 and 91500 were used as primary and secondary zircon standards (Wiedenbeck

520 et al. 1995; Jackson et al. 2004) for elemental and downhole fractionation correction. Raw isotopic

521 data were reduced using the VizualAge ${ }^{\mathrm{TM}}$ workflow in the lolite ${ }^{\mathrm{TM}}$ plugin for Igor Pro ${ }^{\mathrm{TM}}$ (Paton et al. 2011;

522 Petrus and Kamber 2012). The $206 \mathrm{~Pb} / 238 \mathrm{U}$ ages were plotted for all zircons $<850 \mathrm{Ma}$, and

$523207 \mathrm{~Pb} / 206 \mathrm{~Pb}$ for zircon $>850 \mathrm{Ma}$ based in analytical precision and discordance filtering. For display,

524 data were filtered by U-Pb age precision ( $2 \sigma$ error $>10 \%)$ and discordance ( $>10 \%$ between $206 \mathrm{~Pb} / 238 \mathrm{U}$

525 and $207 \mathrm{~Pb} / 235 \mathrm{U}$ ages or $>20 \%$ between $206 \mathrm{~Pb} / 238 \mathrm{U}$ age and $206 \mathrm{~Pb} / 207 \mathrm{~Pb}$ ). Filtering eliminated $<10$

$526 \%$ of all spot analyses. All analytical work was carried out at the UTChron laboratories of the Jacksons

527 School of Geosciences at the University of Texas.

528

529

530

531

532

533

534

535

536

Results

Figure 10 synthetizes all the results obtained on DZs. Sample EC23 ( $n=118)$, ascribed to the PermoTriassic of the Sion-Courmayeur nappe (Fig. 2A) exhibits the youngest group of DZ ages that constraints the maximal depositional age to the Middle Permian (minimum model age: $269 \pm 2 M a, n=3$ ). The Permo-Carboniferous group of DZ (40\% Permian, 37\% Late Carboniferous and $23 \%$ Early Carboniferous) builds a wide peak centred at $315 \mathrm{Ma}$ that includes $34 \%$ of the DZ population. The age range $400-500 \mathrm{Ma}$ is represented by an another $31 \%$ and the so-called "Pan-African" (500 - $800 \mathrm{Ma}$ ) by $23 \%$ of the DZ population. The DZ ages are characterized by a large age-gap between 1050 and 2000 Ma, and Tonian or older ages correspond only to the $7 \%$ of the DZ ages.

Sample EC20 ( $n=134)$, ascribed to the Triassic Vieux Emosson Fm overlying the top basement in the Bonhomme area (Fig. 8C), yielded DZ U-Pb ages predominantly clustering between 400-500 Ma (66\%) and a prominent age peak at $455 \mathrm{Ma}$ (Ordovician). In addition, subsidiary Panafrican (500-800 Ma) and Permo-Carboniferous ( $300 \mathrm{Ma}$ ) DZ age components make up $24 \%$ and $5 \%$ respectively, of the sample 
5421020 and $1960 \mathrm{Ma}$, although Paleoproterozoic and older DZ ages are very scarce.

543 Sample EC16 ( $n=151)$, collected at the base of the Grès Singuliers unit in the Bonhomme area (Fig. 8C), 544 exhibits a complex Palaeozoic and Neoproterozoic DZ age spectrum, with $35 \%$ of the ages belonging to the Permo-Carboniferous period - specifically $13 \%$ Permian; $45 \%$ from $300-325 \mathrm{Ma}$ and $42 \%$ from 325-360 Ma. Another 32\% of the DZ ages scatter between 395 and $500 \mathrm{Ma}$ and display two age peaks at $405 \mathrm{Ma}(9 \%$ of total DZ ages) and $460 \mathrm{Ma}(23 \%)$ respectively. The "Pan-African component" is represented by $30 \%$ of the DZ ages, with minor age peaks at $545 \mathrm{Ma}, 630 \mathrm{Ma}, 700 \mathrm{Ma}$, and $790 \mathrm{Ma}$. Only 4 DZ ages (<3 \%) are older than $850 \mathrm{Ma}$ and none between 1010 and $2020 \mathrm{Ma}$. Sample EC17 ( $n=180)$, collected at the top of the Grès Singuliers unit in the Bonhomme area (Fig. $8 C$ ), showed $\mathrm{U}-\mathrm{Pb}$ ages that fall into three main age components. In this sample, $30 \%$ of the $\mathrm{DZ}$ ages are Permo-Carboniferous with a dominant peak at $335 \mathrm{Ma}$. More specifically, the Permo-Carboniferous ages include 2\% Permian, 28\% from 299-325 Ma, and 70\% from 325-360 Ma). Overall, $>95 \%$ of the Permo-Carboniferous DZ ages are older than 310 Ma. A second age component, representing $37 \%$ of the samples' DZ age, is centred around $470 \mathrm{Ma}$, with most of the ages between 450 and $480 \mathrm{Ma}$. The "Pan-African" mode represents $26 \%$ of the DZ ages and is characterized by peaks at $540 \mathrm{Ma}, 620 \mathrm{Ma}$, and $700 \mathrm{Ma}$. Only $6 \mathrm{DZ}$ ages are older than $850 \mathrm{Ma}$ and none between 990 and $1750 \mathrm{Ma}$.

Sample CR-MB-1B ( $n=148$ ), collected at the base of the Grès Singuliers unit in the Catogne section (Fig.

559 9), is characterized by $45 \%$ Permo-Carboniferous DZ ages that can be subdivided into $22 \%$ Permian, 48\% from 299-325 Ma, and 30\% from 325-360 Ma). A second important age component (31\%) is centred near the Silurian-Ordovician boundary, spreading from 400 to $500 \mathrm{Ma}$. "Pan-African" DZ ages cluster between 500 and 850 and comprise $16 \%$ of the total age spectra. Only $5 \%$ of the sample's ages are $>850 \mathrm{Ma}$ and none are between 1200-1800 Ma. 
299-325 Ma, and 56\% from 325-360 Ma. Another major age component (40\%) clusters between 400500 Ma with an age peak centred at 470 Ma. Lastly $21 \%$ of the ages are "Pan-African", $8 \%$ older than $850 \mathrm{Ma}$, and none between 1100 and $1800 \mathrm{Ma}$.

\section{Interpretation}

The Grès Singuliers unit in both Bonhomme and Catogne areas is characterized by very similar DZ U$\mathrm{Pb}$ age spectra - a typical age-gap from 1200 to $1700 \mathrm{Ma}$, strong Early and Late Palaeozoic magmatic and metamorphic overprints - that suggest a direct or indirect provenance from Cadomian basement.This type of source is typical for the Alpine realm. The pre-Mesozoic basement of the ECMs mainly consist of Cadomian basement intruded during the Variscan by voluminous felsic plutons of mostly Carboniferous to earliest Permian age (e.g. Von Raumer et al. 2013; Grosjean et al. 2018). More specifically, the Mont Blanc - Aiguilles Rouges ECMs comprise, (1) undated Cadomian (?) gneisses, (2) Ordovician plutons, such as the Val Bérard granite (464₫5Ma; Bussy et al. 2011) and the Lognan granite

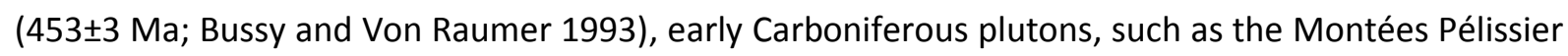
and the Pormenaz granites (both dated at $331 \pm 2$ Ma; Bussy et al. 2000), late Carboniferous- earliest Permian plutons, such as the Mont Blanc granite (303 \pm 2 Ma` Bussy and Von Raumer 1993), the Morcles microgranite (303 $\pm 2 \mathrm{Ma}$; Grosjean et al. 2018) and the Vallorcine granite (306.5 $\pm 1.5 \mathrm{Ma}$; Bussy et al. 2000), and Carboniferous-earliest Permian volcanic rocks, as for example interbedded with fluvial deposits in the Salvan-Dorénaz basin (Capuzzo and Bussy 2000).

In light of published U-Pb ages for the Alpine basement and our new DZ U-Pb data, the Aiguilles Rouges and Mont Blanc crystalline basement appears to be the most likely provenance sources for the Late Carboniferous-early Permian DZ of the Grès Singuliers unit. However, recycling of Permo-Triassic strata (EC23) from the sedimentary cover can also have significantly contributed to the observed DZ U-Pb age signatures. A major contribution of the younger, autochthonous, Triassic strata (EC20, Triassic Vieux Emosson Fm) is unlikely, as the latter distinctively lack the Permian-Carboniferous age peak. In detail, the temporal evolution of DZ U-Pb age spectra of the Grès Singuliers unit displays subtle variations and trends observed in both localities. Within the Permo-Carboniferous age spectra, we 
observe from the base to the top of the Grès Singuliers unit a relative decrease in Permian and Pennsylvanian-Serpukhovian ages and a concomitant increase in Early Carboniferous, mainly Visean, DZ ages. This change however appears more pronounced in the Mt. Catogne area in the north and more subtle in the Bonhomme area in the south. Stratigraphically upsection, the peak of the early Palaeozoic DZ ages (400-500 Ma) appears to be progressively displaced toward older ages, from 450 Ma to $\sim 70 \mathrm{Ma}$. In line with observation of a rift-related detachment fault, the DZ evolution could reflect the progressive exhumation and unroofing of the ECMs (Mont Blanc) basement sources during rifting.

\section{DISCUSSION}

\section{Tectono-sedimentary evolution of the Mont Blanc massif and proximal European margin during necking}

During Hettangian to Early Sinemurian times numerous fault-bounded half-grabens formed, some of which are well preserved along the proximal European margin such as in the Dauphiné domain (i.e. Bourg d'Oisans, La Mure, Taillefer, e.g. Lemoine et al. 1986; Chevalier 2002) and the Helvetic domain (i.e. Morcles and Doldenhorn nappes, e.g. Lemoine et al. 1986; Burkhard 1988; Epard 1990). This first stage of rifting is dominated in the western Helvetic domain by marls and limestones (Fig. 11, i.e. Tierces Fm, Epard 1989; Loup 1991).

During Sinemurian-Pliensbachian time rift activity localized in areas that would evolve into the future distal domain (e.g. Lemoine et al. 1986; Chevalier et al. 2003). This evolution went along with the formation of major extensional detachment systems and related core complex described in this study. Other similar structures are the Grosina detachment system (Mohn et al. 2012) and the GozzanoInvorio-Arona detachment system (Decarlis et al. 2017). Both the latter are located between the proximal and distal margins of the conjugate Adriatic margin and formed during SinemurianPliensbachian time. As explained above on the basis of stratigraphic relationships involving the Grès 
Singuliers unit (Figs 8 and 9), the Mont Blanc detachment system was more-or-less synchronous with them. The formation of the Mont Blanc detachment system thus corresponds to a major reorganization of the depositional systems, which is testified by the large-scale exhumation of pre-rift basement and reworking of pre-rift sedimentary cover both leading to the genesis of the Grès Singuliers unit. The appearance of a local siliciclastic source occurred within an otherwise carbonatedominated depositional system (i.e. Mont Joly Fm, Fig. 11). Where the Grès Singuliers unit directly overlies the exhumed detachment fault, footwall-derived monomict conglomerates are observed (i.e. Amône conglomerate). This conglomerate body shows a variable thickness but can be followed over a distance of more than $10 \mathrm{~km}$ in the Swiss Val Ferret, and is genetically related to detachment faulting the detritus of the Grès Singuliers unit came partly from the resedimentation of fault rocks (i.e. cataclasites and black gouges) and footwall lithologies derived from Late Carboniferous basins, polymetamorphic basement (gneiss), granite and rhyolitic rocks with a variable contribution of preGrès Singuliers unit carbonate lithologies (Fig. 10). The following interpretation of source regions considers the Mont Blanc massif basement (granite and gneiss) and the Late Carboniferous basins that were likely widespread along the ECMs during the time interval of interest. This shows that the detachment and its footwall became available for sedimentation and therefore presented a potential source feeding for the Grès Singuliers depositional system. In this framework, the Grès Singuliers unit represents the sedimentary response to the exhumation of the Mont Blanc basement along the riftrelated Mont Blanc detachment system (i.e. syn-tectonic deposit). Their syn-tectonic character is also evidenced by a range of clastic intrusions observed beneath and within depositional body. density flows, which suggest the uplift and creation of (at least) one trough and adjacent palaeo-highs in the Mont Blanc domain during the late Sinemurian-Pliensbachian (Fig. 11). The formation of the palaeo-high due to footwall exhumation and uplift along the Mont Blanc detachment system explains the reworking of basement rocks. Possible mechanisms for sediment dispersal include wave action in 
643

644

645

646

647

648

649

650

651

652

653

654

655

656

657

658

659

660

661

662

663

664

665

666

667

the shallower areas, the development of subaqueous sediment density flow toward the seaway axis, and tidal currents within the seaway (Fig. 11). No evidence for emersion is found. In this scheme, conglomerates in the Combe des Fonds and l'Amône represent the residual facies preserved on top of the exhuming Mont Blanc system and winnowed by marine (wave-dominated?) processes (Fig. 11). The Bonhomme and Catogne areas are probably zones of interference between gravitational and tractive flow processes as commonly observed in tectonically confined tidal seaways and straits (e.g. Longhitano and Steel 2017, Longhitano, 2013 \#4215). The conglomerates in the Combe des Fonds and I'Amône could represent the residual, shallowest facies preserved on top of the exhuming Mont Blanc system and winnowed by marine (wave?) processes (Fig. 11). Along strike migrating tidal bars and ridges also characterize the syn-necking units in several rift systems such as the North Sea (e.g. Galloway 2002) or the North Atlantic in Greenland and Mid Norway during Latest Jurassic-Earliest Cretaceous (personal communication lan Sharp).

The siliciclastic source of the Grès Singuliers unit is not active anymore from the Toarcian-Aalenian, which is interpreted to reflect either a cessation of footwall uplift of the Mont Blanc detachment system and or/and a subsequent drowning of the whole Helvetic domain. The Toarcian-Aalenian time interval, coeval with hyper-extension system tract in the Alpine Tethys margins (hyper-extension system tract sensu Ribes et al. 2019b), is in the Mont Blanc are characterized by the deposition of black marls and limestone of the Toarcian Monts Rossets Fm overlain by the black lime-free shales of the Dugny Fm (e.g. Epard 1989; Loreau et al. 1995). These formations observed in the overall Helvetic domain are interpreted to record a general drowning generally understood as an overall sediment starvation (e.g. Loreau et al. 1995) combined to significant carbonate switch off related to the Early Toarcian oceanic anoxic event (e.g. Fantasia et al. 2018).

The Toarcian-Aalenian time interval thus marks the end of tectonic activity in the Helvetic domain, which can be understood as the effect of the migration of the deformation toward more distal parts of the margin as recorded in the stratigraphic record of the distal margins (e.g. Ribes et al. 2019b). 
Distally to the study are, syn-kinematic facies related to the hyper-extension may be represented by breccia deposit observed in the Moûtiers Unit (i.e. distal European margin, Ribes et al. 2019a), corresponding to the Dent d'Arpire Fm (Loprieno 2001) also named Brèches du Grand Fond Fm or Brèches de la Tarentaise (e.g. Antoine et al. 1972; Fudral 1973). The final stage of rifting closing the syn-rift megasequence is marked by the exhumation of mantle and onset of magma in the Valais domain (Sion-Courmayeur and Tasna nappes; Beltrando et al. 2012; Ribes et al. 2019a) and the contemporaneous deposition of the Callovo-Oxfordian "Terres Noires" in the Helvetic and Dauphinois domains (Figs 2 and 11).

\section{The Mont Blanc Core Complex (MBCC)}

The development of gravity-driven depositional systems at the base of the Grès Singuliers unit, the thinning trend of the Grès Singuliers unit toward the central part of the Mont Blanc massif, and the facies distribution along the Swiss Val Ferret suggest that the exhumed basement of the Mont Blanc massif was an elongated dome-shaped palaeo-high during the Late Early to Middle Jurassic (Fig. 11). The occurrence of such a palaeo-high was already suggested by Trümpy (1971) and Loup (1991): the "Mont Blanc Island". These authors, however, suggested that this high represented a relict of the Triassic paleotopography. This view is in contrasts with our interpretation proposing a true tectonic uplift during the Late Early to Middle Jurassic. The residual Triassic "island" is moreover in contradiction with the detrital zircon record indicating that the clastic source of Grès Singuliers significantly differs from that of the Triassic Vieux Emosson Fm (Fig. 10). This view is contrasts with our interpretation assuming a tectonic uplift during the Late Early to Middle Jurassic. Similar uplifts linked to crustal thinning have also been observed in several rifted margins (e.g. Pik et al. 2013; Lewis 2014) and predicted more recently by numerical modelling (Chenin et al. 2019).

The top basement extensional detachment fault system currently outcrops discontinuously across $50 \mathrm{~km}$ along the Mont Blanc massif, here referred to as the Mont Blanc core complex (MBCC). The 
extensional detachment fault and associated core complex show similarities to those described from the southwestern United States and elsewhere (Wernicke 1985; Buck 1988; Lister and Davis 1989; Axen and Karner 2005; Platt et al. 2015). Its overall dome shape is reminiscent of present-day core complex (e.g. Brun et al. 2018). The domal geometry of the footwall of core complexes has been explained as resulting from a combination of isostatic/flexural uplift of the detachment when the hanging-wall rocks are extended, thinned, and denuded by rolling hinge process (e.g. Spencer 1984; Wernicke and Axen 1988; Whitney et al. 2013 references therein). Continental core complexes are typically elliptical, with a long axis of $\sim 10-40 \mathrm{~km}$; the footwall of core complexes is typically elevated above the surrounding hanging wall, creating the dome shape structure made of exhumed footwall rocks that can create up to 1-2 km of relief (e.g. Whitney et al. 2013 references therein).

With a rolling hinge process, the MBCC and associated detachment fault system could result from the sequential development of high-angle normal faults occurring above the Aiguilles Rouges-Mont Blanc massifs (Fig. 11). With increasing extension and footwall isostatic and flexural rebound, each new fault is rotated to a low dip then abandoned as a new fault develops in the hanging wall (e.g. Brun et al. 2018 references therein).

An example of active detachment faults producing a metamorphic core complex related to rifting and opening of a small ocean basin has been described from the Woodlark-D'Entrecasteaux rift system (Papua New Guinea, e.g. Little et al. 2007; Daczko et al. 2009). Associated to one of these dome-shaped metamorphic core complexes, syn-kinematic (i.e. syn-detachment and syn-footwall uplift) conglomerates and sandstones derived from the exhumed footwall are observed around the Suckling- Dayman MCC (Gwoira Conglomerate and Uba Sandstone, e.g. Webber 2017; Little et al. 2019). The development of these core complex-derived sediments present convincing tectonosedimentary similarities with the Grès Singuliers unit deposited around the MBCC.

\section{Relics of Alpine Tethys necking zones and associated clastic units}


The paleographic position of the Aiguilles Rouges-Mont Blanc ECM between the proximal and distal

719 European margins has enabled some authors to interpret it as a necking domain (e.g. Beltrando et al. 2014; Mohn et al. 2014). Based on the study of present-day rifted margins, the necking domain corresponds to the region where the continental crust thins abruptly from $30-35$ to $10 \mathrm{~km}$ between the proximal and distal domains (e.g. Sutra and Manatschal 2012; Peron-Pinvidic et al. 2013; Tugend et al. 2015). A necking system tract has been defined by Ribes et al. (2019), which encompasses the syn-tectonic sedimentary wedge coeval with formation of this specific domain. Extension related to the necking tectonic system tract is characterized by the localization along a few major upper and lower crustal faults exhuming basement rocks along large scale detachment faults (e.g. Mohn et al. 2012; Beltrando et al. 2015). In such systems, the pre-rift succession becomes progressively delaminated along multiple detachment faults resulting in the formation of extensional allochthons and slivers overriding the top basement detachment faults (e.g. Mohn et al. 2015). The identification of the Mont Blanc core complex associated to a large detachment system and specific deformation processes (cataclasis, gouge) strengthen the interpretation of: (i) the Mont Blanc region as the breakaway of a former necking zone along the European margin, and (ii) the Grès Singuliers unit as a syn-tectonic sedimentary wedge deposited in response to the necking of the continental crust. In this scheme, the angular unconformity observed at the base of the Grès Singuliers unit is understood as the stratigraphic surface marking the onset of the necking system tract (e.g. Ribes et al. 2019b).

From a stratigraphic point of view, the recognition of localized, in time and space, siliciclastic facies, such as the Grès Singuliers unit, derived from an uplifted exhumed basement and reworking of its overlying pre-rift sedimentary cover during the Sinemurian-Pliensbachian is understood as an indicator of necking processes. Interestingly, during the late Early Jurassic, siliciclastic facies are observed above or near several of the Alpine ECMs while the surrounding, more proximal domains, including the Dauphinois and Helvetic domains are characterized by limestone and shale deposits (Trümpy 1971; Barfety and Mouterde 1980). In the Aar massif region, both the autochthonous sedimentary cover outcropping in the Raron syncline and the para-autochthonous sedimentary cover outcropping in the 
Doldenhorn nappe present siliciclastic facies (Fig. 2; Loup 1991). The latter are characterized by sandstones mainly composed of angular to sub-angular quartz, altered feldspar and dolomitic grains split into two intervals, one dated from the Late Sinemurian and the second from the Pliensbachian (Loup 1991 and references therein). In the Ferden area (Fig. 2A and C), both sandstone intervals present indicators of tidal processes (herringbones cross-stratification and high-angle sigmoidal foresets, Loup 1991). The Early to Middle Jurassic lithologies and vertical succession present strong similarities with the sedimentary cover of the Mont Blanc and particularly with the Saillon section (Fig. 9). The position of the Gastern-Aar massif along the European margin (e.g. hingeline of Stockmal \& Beaumont (1987)), as well as the development of siliciclastic sediments around it during a specific time interval, late Sinemurian-Pliensbachian are reminiscent of what is observed in the Mont Blanc region with the Grès Singuliers unit.

Although an extrapolation to the other ECMs is premature and requires further investigation, we note that also in the vicinity of the Pelvoux massif, conglomerates and sandstones dated as Pliensbachian are described by Barfety and Mouterde (1980), while during that period the overall Dauphinois domain is characterized by limestone and shales (Barfety 1985). Furthermore, the description made by Wibberley (1999) of brittle damage zones with cataclasites and highly sheared black phyllosilicate-rich fault rocks in the granitic basement of the Pelvoux is similar to what has been observed from well described Jurassic extensional detachment faults (Manatschal 1999). In the northern Adriatic margin, Mohn et al $(2011 ; 2012)$ has identified relics of a necking zone in the Campo-Grosina nappe based on the recognition of crustal scale detachments exhuming pre-rift middle/lower crust at the seafloor during the rifting (i.e. Grosina detachment). However, no sedimentary cover has been preserved above the tectonically exhumed Grosina detachment. Recognition of crustal scale detachments exhuming pre-rift middle/lower crust have also allowed Beltrando et al. (2015) and Decarlis et al. (2017) to interpret the Gozzano-Invorio-Arona zone as the former necking zone of the southern Adriatic margin. Interestingly, siliciclastic facies are also observed 
in this zone during the Pliensbachian to early Toarcian (i.e. Invorio Breccia and San Quirico sandstone; e.g. Berra et al. 2009; Beltrando et al. 2015; Decarlis et al. 2017). These facies that overlie unconformably karstified middle Triassic dolostone and Permian volcanic rocks are interpreted as indicative of widespread subaerial exposure of Permian volcanic rocks and metamorphic basement (Beltrando et al. 2015).

\section{The MBCC: a fossil analogue for necking domains in present-day rifted margins}

Lithospheric-scale low-angle detachment faults and associated core complexes at continental rifted margins have been first proposed by Lister et al. $(1986 ; 1991)$. Thereafter, core complexes flanked by large-scale detachment structures exhuming mid crustal rocks have been recognized in the necking zone of the Iberia margin (i.e. west Galicia Bank, e.g. Peron-Pinvidic et al. 2013), the Norwegian margin (i.e. Gossa High, e.g. Osmundsen and Ebbing 2008; Osmundsen and Péron-Pinvidic 2018), the Angola margin (e.g. Unternehr et al. 2010), the Eritrea margin (i.e. Damas and Burri highs in Talbot and Ghebreab 1997) and numerically modeled (e.g. Peron-Pinvidic and Naliboff 2020). These observations at various rifted margins suggest that detachment faults and associated core complexes in necking domains of rifted margins are frequently observed. However, the $\mathrm{MBCC}$ is at present the only field analogue world-wide where the tectono-sedimentary evolution can be constrained and integrated into the evolution of a whole margin system (e.g. Ribes et al. 2019b).

The necking domain of the south Australian rifted margin, in the Great Australian Bight, shows a remarkable dome-shaped architecture and associated sequential high-angle normal faults, similar to what can be reconstructed in the Mont Blanc region (Fig. 12). This margin and its Antarctic conjugate formed during the fragmentation of Gondwanaland. The first phase of rifting probably initiated during the Triassic-Jurassic (Veevers 2012). Seismic sections across the necking area clearly show that the proximal domain is affected by several major normal faults forming half-grabens filled with wedges of syn-tectonic sediments, which have been drilled at the Jerboa-1 site (Totterdell et al. 2000). Some of the blocks appear to be overtilted (i.e. intersection of normal fault and block surface is less than $60^{\circ}$ ) 
and a decreasing size of the faulted blocks toward the ocean is observed. The necking domain itself marks a sharp transition from a thick $(30 \mathrm{~km})$ to an extremely thin (less than $7.5 \mathrm{~km}$ ) continental basement (Ball et al. 2013). The architecture and organization of the normal faults and the dome shape of the necking domain may be a modern analogue for the outer European margin preserved in the Helvetic nappes. However, an alternative interpretation could it be to consider this surface as a large footwall erosional unconformity that developed during the necking time such as suggested for the Skinna Ridge, Frøya High, Gossa High in Mid Norway (e.g. Osmundsen and Péron-Pinvidic 2018).

The implications of this work for present-day margins are that the sediments of the necking system tract, recording the development of large-scale detachment systems, are characterized by a major reorganization of the pre-necking depositional systems typified by the development of footwallderived clastic sedimentary systems. The recognition of these clastic sediments, which are spatially related to the necking zone and limited in time to the necking system tract, allow a better understanding of the overall rifting history, differentiating a specific time interval within the the synrift megasequence. The creation of a transient uplift recorded by the Mont Blanc core complex lead to the development of an unconformity at the base of the Grès Singuliers unit, which is understood as the marker for the onset of the necking. This stratigraphic surface, corresponding to the lower bounding surface, typifies a necking unconformity. It separates the sediment of the necking system tract from those belonging to the preceding stretching system tract (e.g. Ribes et al. 2019b). The top of the Grès Singuliers unit that marks the base of the post-tectonic package in the necking domain is understood as the 'onset of hyper-extension' surface.

\section{CONCLUSIONS}

The Grès Singuliers unit represents an anomalous occurrence of a clastic facies in a very limited geographic area above the Mont Blanc massif, which was emplaced during Jurassic rifting. The main aim of this contribution was to integrate and reconcile sedimentological, stratigraphic and tectonic 
data to provide a tectono-sedimentary framework for the Mont Blanc massif and explain its evolution during Jurassic rifting.

The Early Jurassic rift-related structures characterized by cataclasites and black gouges observed at the top of the Mont Blanc basement highlight a detachment fault system flanking a core complex here referred to as the Mont Blanc core complex (MBCC). This system is associated with a large-scale detachment system that is located between the proximal and distal margins, supporting the idea that the Mont Blanc region hosts the breakaway area of a necking zone of the European margin.

The Grès Singuliers unit originated from a siliciclastic-dominated sedimentary system, including clastsupported conglomerates, lithic arenites to quartz arenites and sandy limestones that unconformably overlie the Lower Jurassic to Triassic carbonates and, in places, directly onlap the exhumed basement of the Mont Blanc massif. Based on the facies distribution, petrographic analysis and detrital zircon provenance, we have demonstrated that the Grès Singuliers unit is mainly derived from the erosion of the footwall of the Mont Blanc core complex. Depositional systems comprise density flow deposits originating from fault escarpments linked to the Mont Blanc core complex exhumation, that evolve, in time to sediments that show evidence for reworking by tidal currents.

The source to sink relationship between the Mont Blanc core complex and the Grès Singuliers unit allows us to consider the Grès Singuliers unit as the sedimentary response to crustal necking during rifting. They represent a syn-tectonic sediment body constituting a necking system tract within a larger scale syn-rift megasequence. The main result of this study is to show that the exhumation and uplift of basement during the necking system tract produce a new but temporary source area for rift-related clastic sedimentary systems. Thus, the position of the Grès Singuliers along the margin is symptomatic of a necking area within a wider rift domain. 
Amberger G-F (1959) L'autochtone de la partie Nord-Quest du massif des Aiguilles Rouges: HauteSavoie et Valais. University of Geneva

Antoine P, Barbier R, Debelmas J, Fudral S (1972) Précisions chronologiques et paléogéographiques sur les breches du Massif du Grand-Fond (zone des Breches de Tarentaise, Savoie) Géol Alp 48:4959

Antoine P, Pairis J, Pairis B (1975) Quelques observations nouvelles sur la structure de la couverture sedimentaire interne du massif du Mont-Blanc, entre le col Ferret (frontiere italo-suisse) et la Tete des Fours (Savoie, France) Géologie alpine 51:5-23

Avanzini M, Cavin L (2009) A new Isochirotherium trackway from the Triassic of Vieux Emosson, SW Switzerland: stratigraphic implications Swiss Journal of Geosciences 102:353-361

Aviolat P (1991) Géologie de la couverture sédimentaire du Mont-balnc interne et des Unités Helvetiques dans le val Ferret Italien Master Thesis, Université de Lausanne

Axen GJ, Karner G (2005) Mechanics of low-angle normal faults Rheology and deformation of the lithosphere at continental margins:46-91

Badoux H (1963) Les unités ultrahelvétiques de la Zone des Cols Eciogae Geologicae Helvetiae 56:1-13

Ball P, Eagles G, Ebinger C, McClay K, Totterdell J (2013) The spatial and temporal evolution of strain during the separation of Australia and Antarctica Geochemistry, Geophysics, Geosystems 14:2771-2799

Barfety J, Mouterde R (1980) Évolution des faciès du Jurassique dans la zone dauphinoise du MontBlanc au Pelvoux (Alpes occidentales) Bulletin de la Société géologique de France série 7:557565

Barfety JC (1985) Le Jurassique dauphinois entre Durance et Rhône: étude stratigraphique et géodynamique; évolution d'une portion de la marge nord téthysienne (Alpes occidentales françaises). Université Scientifique et Médicale de Grenoble

Baumgartner PO (2013) Mesozoic radiolarites-accumulation as a function of sea surface fertility on Tethyan margins and in ocean basins Sedimentology 60:292-318

Beltrando M, Frasca G, Compagnoni R, Vitale-Brovarone A (2012) The Valaisan controversy revisited: Multi-stage folding of a Mesozoic hyper-extended margin in the Petit St. Bernard pass area (Western Alps) Tectonophysics 579:17-36 doi:10.1016/j.tecto.2012.02.010

Beltrando M, Manatschal G, Mohn G, Dal Piaz GV, Brovarone AV, Masini E (2014) Recognizing remnants of magma-poor rifted margins in high-pressure orogenic belts: The Alpine case study EarthScience Reviews 131:88-115 doi:10.1016/j.earscirev.2014.01.001

Beltrando M, Stockli DF, Decarlis A, Manatschal G (2015) A crustal-scale view at rift localization along the fossil Adriatic margin of the Alpine Tethys preserved in NW Italy Tectonics 34:1927-1951 doi:10.1002/2015TC003973

Berra F, Galli MT, Reghellin F, Torricelli S, Fantoni R (2009) Stratigraphic evolution of the TriassicJurassic succession in the Western Southern Alps (Italy): the record of the two-stage rifting on the distal passive margin of Adria Basin Research 21:335-353 doi:10.1111/j.13652117.2008.00384.x

Bill M, O'Dogherty L, Guex J, Baumgartner PO, Masson H (2001) Radiolarite ages in AlpineMediterranean ophiolites: Constraints on the oceanic spreading and the Tethys-Atlantic connection GSA Bulletin 113:129-143 doi:10.1130/00167606(2001)113<0129:RAIAMO>2.0.CO;2

Brun J-P, Sokoutis D, Tirel C, Gueydan F, Van den Driessche J, Beslier M-O (2018) Crustal versus mantle core complexes Tectonophysics 746:22-45

Buck WR (1988) Flexural rotation of normal faults Tectonics 7:959-973

Burkhard M (1988) L'Helvétique de la bordure occidentale du massif de l'Aar (évolution tectonique et métamorphique) Eclogae Geologicae Helvetiae 81:63-114 
Bussy F, Hernandez J, Von Raumer J (2000) Bimodal magmatism as a consequence of the postcollisional readjustment of the thickened Variscan continental lithosphere (Aiguilles RougesMont Blanc Massifs, Western Alps) Earth and Environmental Science Transactions of The Royal Society of Edinburgh 91:221-233

Bussy F, Péronnet V, Ulianov A, Epard J, Von Raumer J (2011) Ordovician magmatism in the external French Alps: Witness of a peri-Gondwanan active continental margin The Ordovician of the World: Madrid, Instituto Geológico y Minero de España, Cuadernos del Museo Geominero 14:75-82

Bussy F, Von Raumer J (1993) U-Pb dating of Palaeozoic events in the Mont-Blanc crystalline massif, Western Alps Terra Nova 5:382-383

Capuzzo N, Bussy F (2000) High-precision dating and origin of synsedimentary volcanism in the Late Carboniferous Salvan-Dorénaz basin (Aiguilles-Rouges Massif, Western Alps) Schweizerische Mineralogische und Petrographische Mitteilungen 80:147-167

Capuzzo N, Wetzel A (2004) Facies and basin architecture of the Late Carboniferous Salvan-Dorénaz continental basin (Western Alps, Switzerland/France) Sedimentology 51:675-697

Cardello GL, Di Vincenzo G, Giorgetti G, Zwingmann H, Mancktelow N (2019) Initiation and development of the Pennine Basal Thrust (Swiss Alps): a structural and geochronological study of an exhumed megathrust Journal of Structural Geology 126:338-356

Carr ID, Gawthorpe RL, Jackson CA, Sharp IR, Sadek A (2003) Sedimentology and sequence stratigraphy of early syn-rift tidal sediments: the Nukhul Formation, Suez Rift, Egypt Journal of Sedimentary Research 73:407-420

Chenin P, Manatschal G, Decarlis A, Schmalholz SM, Duretz T, Beltrando M (2019) Emersion of Distal Domains in Advanced Stages of Continental Rifting Explained by Asynchronous Crust and Mantle Necking Geochemistry, Geophysics, Geosystems 20:3821-3840

Chester F, Logan JM (1986) Implications for mechanical properties of brittle faults from observations of the Punchbowl fault zone, California Pure and applied geophysics 124:79-106

Chevalier F (2002) Vitesse et cyclicité de fonctionnement des failles normales de rift: implication sur le remplissage stratigraphique des bassins et sur les modalités d'extension d'une marge passive fossile: aplication au demi-graben liasique de Bourg-d'Oisans (Alpes occidentales, France). PhD, Université de Bourgogne

Chevalier F, Guiraud M, Garcia JP, Dommergues JL, Quesne D, Allemand P, Dumont T (2003) Calculating the long-term displacement rates of a normal fault from the high-resolution stratigraphic record (early Tethyan rifting, French Alps) Terra Nova 15:410-416 doi:10.1046/j.13653121.2003.00508.x

Clerc C, Lagabrielle Y, Labaume P, Ringenbach J-C, Vauchez A, Nalpas T, Bousquet R, Ballard J-F, Lahfid A, Fourcade S (2016) Basement-Cover decoupling and progressive exhumation of metamorphic sediments at hot rifted margin. Insights from the Northeastern Pyrenean analog Tectonophysics 686:82-97

Crespo-Blanc A, Masson H, Sharp Z, Cosca M, Hunziker J (1995) A stable and 40Ar/39Ar isotope study of a major thrust in the Helvetic nappes (Swiss Alps): evidence for fluid flow and constraints on nappe kinematics Geological Society of America Bulletin 107:1129-1144

Daczko N, Caffi P, Halpin JA, Mann P (2009) Exhumation of the Dayman dome metamorphic core complex, eastern Papua New Guinea Journal of Metamorphic Geology 27:405-422

De Saussure H-B (1779) Voyages dans les Alpes. Neuchâtel

Debelmas J, Lemoine M (1970) The western Alps: palaeogeography and structure Earth-Science Reviews 6:221-256

Decarlis A, Beltrando M, Manatschal G, Ferrando S, Carosi R (2017) Architecture of the Distal PiedmontLigurian Rifted Margin in NW Italy: Hints for a Flip of the Rift System Polarity Tectonics 36:23882406 doi:10.1002/2017TC004561

Desmurs L, Manatschal G, Bernoulli D (2001) The Steinmann Trinity revisited: mantle exhumation and magmatism along an ocean-continent transition: the Platta nappe, eastern Switzerland 
Geological Society, London, Special Publications

doi:10.1144/GSL.SP.2001.187.01.12

Duparc L, Mrazec L, Pearce M-F (1901) Carte géologique du massif du Mont-Blanc Le Globe Revue genevoise de géographie 40:163-167

Duparc L, Pearce F (1989) Sur le Poudingue de l'Amône dans le Val Ferret suisse Comptes rendus de l'Académie des sciences 126:1-3

Egli D, Mancktelow N (2013) The structural history of the Mont Blanc massif with regard to models for its recent exhumation Swiss Journal of Geosciences 106:469-489

Eltchaninoff-Lancelot C (1980) Etude géologique entre Belledonne et Mont-Blanc: la terminaison méridionale du massif du Mont-Blanc et les terrains de son enveloppe. PhD, Université Pierre et Marie Curie de Paris

Eltchaninoff-Lancelot C, Triboulet S, Doudoux B, Fudral S, Rampnoux J-P, Tardy M (1982) Stratigraphie et tectonique des unites delphino-helvetiques comprises entre Mont-Blanc et Belledonne (Savoie-Alpes occidentales); Implications regionales Bulletin de la Société géologique de France 7:817-830

Eltchaninoff C, Triboulet S (1980) Étude Géologique entre Belledonne et Mont Blanc (Livre synthétique) Travaux du Département de Géotectonique de l'Université Pierre et Marie Curie de Paris:1-54

Elter G, Elter P (1964) Carta geologica della regione del Piccolo San Bernardo (versante italiano). Centro nazionale per lo studio geologico e petrografico delle Alpi,

Epard J-L (1986) Le contact entre le socle du Mont Blanc et la zone de Chamonix, implications tectoniques BULLETIN DE LA SOCIETE VAUDOISE SCIENCES NATURELLES 288

Epard J-L (1989) Stratigraphie du Trias et du Lias dauphinois entre Belledone, Aiguilles-Rouges et MontBlanc Bulletin de la Societe Vaudoise des Sciences Naturelles 304 doi:10.5169/seals-279237

Epard JL (1990) La nappe de Morcles au sud-ouest du Mont-Blanc vol 8. Lausanne

Epin M-E, Manatschal G (2018) Three-dimensional architecture, structural evolution and role of inheritance controlling detachment faulting at a hyperextended distal margin: The example of the Err detachment system (SE Switzerland) Tectonics 37 doi:10.1029/2018TC005125

Escher A, Hunziker J, Marthaler M, Masson H, Sartori M, Steck A (1997) Geological framework and structural evolution of the Western Swiss-Italian Alps Deep Structure of the Swiss Alps: Results of the National Research Program 20 (NRP 20):205-222

Escher A, Masson H, Steck A (1993) Nappe geometry in the western Swiss Alps Journal of Structural Geology 15:501-509

Fantasia A, Föllmi KB, Adatte T, Spangenberg JE, Montero-Serrano J-C (2018) The Early Toarcian oceanic anoxic event: Paleoenvironmental and paleoclimatic change across the Alpine Tethys (Switzerland) Global and Planetary Change 162:53-68

Favre A (1867) Recherches géologiques dans les parties de la Savoie, du Piémont et de la Suisse voisines du Mont-Blanc: 3 vol 3. Masson,

Finger F, Steyrer H (1990) I-type granitoids as indicators of a late Paleozoic convergent ocean-continent margin along the southern flank of the central European Variscan orogen Geology 18:12071210

Froitzheim N, Eberli GP (1990) Extensional detachment faulting in the evolution of a Tethys passive continental margin, Eastern Alps, Switzerland Geological Society of America Bulletin 102:12971308

Froitzheim N, Rubatto D (1998) Continental breakup by detachment faulting: field evidence and geochronological constraints (Tasna nappe, Switzerland) Terra Nova 10:171-176

Fudral S (1973) Contribution à l'étude de l'unité de Moutiers (zone des brêches de Tarentaise) entre le vallon du torrent du Cormet d'Arêches et le hameau des Chapieux (Savoie)-Alpes françaises. $\mathrm{PhD}$, Université Scientifique et Médicale de Grenoble

Funk H, Oberhänsli R, Pfiffner A, Schmid S, Wildi W (1987) The evolution of the northern margin of the Tethys in eastern Switzerland Episodes 10:102-106 
Galloway W (2002) Paleogeographic setting and depositional architecture of a sand-dominated shelf depositional system, Miocene Utsira Formation, North Sea Basin Journal of Sedimentary Research 72:476-490

Grasmück KP (1961) Die helvetischen Sedimente am Nordostrand des Mont Blanc-Massivs (zwischen Sembrancher und dem Col Ferret) Eclogae geologicae Helvetiae 54

Grosjean DB, Meisser N, May-Leresche S, Ulianov A, Vonlanthen P (2018) The Morcles microgranite (Aiguilles Rouges, Swiss Alps): Geochronological and geochemical evidences for a common origin with the Vallorcine intrusion Swiss Journal of Geosciences 111:35-49

Guermani A, Pennacchioni G (1998) Brittle precursors of plastic deformation in a granite: an example from the Mont Blanc massif (Helvetic, western Alps) Journal of Structural Geology 20:135-148

Hart NR, Stockli DF, Hayman NW (2016) Provenance evolution during progressive rifting and hyperextension using bedrock and detrital zircon $\mathrm{U}-\mathrm{Pb}$ geochronology, Mauléon Basin, western Pyrenees Geosphere 12:1166-1186

Hubbard RJ (1988) Age and significance of sequence boundaries on Jurassic and Early Cretaceous rifted continental margins AAPG bulletin 72:49-72

Incerpi N, Martire L, Manatschal G, Bernasconi SM (2017) Evidence of hydrothermal fluid flow in a hyperextended rifted margin: the case study of the Err nappe (SE Switzerland) Swiss Journal of Geosciences:1-18 doi:10.1007/s00015-016-0235-2

Jackson SE, Pearson NJ, Griffin WL, Belousova EA (2004) The application of laser ablation-inductively coupled plasma-mass spectrometry to in situ $\mathrm{U}-\mathrm{Pb}$ zircon geochronology Chemical Geology 211:47-69

Jeanbourquin P, Goy-Eggenberger D (1991) Mélanges suprahelvétiques: sédimentation et tectonique au front de la nappe de Morcles (Vaud, Suisse) Géologie alpine 67:43-62

Jolly RJ, Lonergan L (2002) Mechanisms and controls on the formation of sand intrusions Journal of the Geological Society 159:605-617

Kreisa R, Moila R (1986) Sigmoidal tidal bundles and other tide-generated sedimentary structures of the Curtis Formation, Utah Geological Society of America Bulletin 97:381-387

Labaume $P$ (1987) Syn-diagenetic deformation of a turbiditic succession related to submarine gravity nappe emplacement, Autapie Nappe, French Alps Geological Society, London, Special Publications 29:147-163

Lagabrielle Y, Clerc C, Vauchez A, Lahfid A, Labaume P, Azambre B, Fourcade S, Dautria J-M (2016) Very high geothermal gradient during mantle exhumation recorded in mylonitic marbles and carbonate breccias from a Mesozoic Pyrenean palaeomargin (Lherz area, North Pyrenean Zone, France) Comptes Rendus Geoscience 348:290-300

Landry P (1976) Contribution à l'étude géologique de la région de Roselend (Savoie)-Alpes françaises. Université Scientifique et Médicale de Grenoble

Landry P (1978) Données nouvelles sur la couverture sédimentaire des mas-sifs cristallins externes au Sud du Mont-Blanc Géologie alpine 54:83-110

Leloup P-H, Arnaud N, Sobel ER, Lacassin R (2005) Alpine thermal and structural evolution of the highest external crystalline massif: The Mont Blanc Tectonics 24 doi:10.1029/2004tc001676

Lemoine M, Bas T, Arnaud-Vanneau A, Arnaud H, Dumont T, Gidon M, Bourbon M, de Graciansky P-C, Rudkiewicz J-L, Megard-Galli J (1986) The continental margin of the Mesozoic Tethys in the Western Alps Marine and Petroleum Geology 3:179-199

Lemoine M, Trümpy R (1987) Pre-oceanic rifting in the Alps Tectonophysics 133:305-320

Lewis DS (2014) New Insights into Late Synrift Subsidence from Detailed Well Ties and Seismic Mapping, Campos Basin, Brazil Sedimentary basins: Origin, depositional histories and petroleum systems:98-115

Li X-H, Faure M, Lin W, Manatschal G (2013) New isotopic constraints on age and magma genesis of an embryonic oceanic crust: the Chenaillet Ophiolite in the Western Alps Lithos 160:283-291

Liati A, Froitzheim N, Fanning CM (2005) Jurassic ophiolites within the Valais domain of the Western and Central Alps: geochronological evidence for re-rifting of oceanic crust Contributions to Mineralogy and Petrology 149:446-461 
Lister G, Etheridge M, Symonds P (1986) Detachment faulting and the evolution of passive continental margins Geology 14:246-250

Lister G, Etheridge M, Symonds P (1991) Detachment models for the formation of passive continental margins Tectonics 10:1038-1064

Lister GS, Davis GA (1989) The origin of metamorphic core complexes and detachment faults formed during Tertiary continental extension in the northern Colorado River region, USA Journal of Structural Geology 11:65-94 doi:10.1016/0191-8141(89)90036-9

Little TA, Baldwin S, Fitzgerald P, Monteleone B (2007) Continental rifting and metamorphic core complex formation ahead of the Woodlark spreading ridge, D'Entrecasteaux Islands, Papua New Guinea Tectonics 26

Little TA, Webber S, Mizera M, Boulton C, Oesterle J, Ellis S, Boles A, van der Pluijm B, Norton K, Seward D (2019) Evolution of a rapidly slipping, active low-angle normal fault, Suckling-Dayman metamorphic core complex, SE Papua New Guinea Geological Society of America Bulletin

Longhitano SG, Mellere D, Steel RJ, Ainsworth RB (2012) Tidal depositional systems in the rock record: a review and new insights Sedimentary Geology 279:2-22

Longhitano SG, Steel RJ (2017) Deflection of the progradational axis and asymmetry in tidal seaway and strait deltas: insights from two outcrop case studies Geological Society, London, Special Publications 444:141-172

Loprieno A (2001) A combined structural and sedimentological approach to decipher the evolution of the Valais domain in Savoy Western Alps [Ph D thesis]: Basel, Switzerland, Universität Basel

Loreau J, Gely J, Rampneaux J (1995) Cycles stratigraphiques dans les séries alpines du Lias et de l'Aalénien de part et d'autre du Front pennique (Savoie, France): Contrôle tectonique et rapport avec l'eustatisme Eclogae Geol Helv 88:529-551

Loup BFR (1991) Evolution de la partie septentrionale du domaine helvétique en Suisse occidentale au Trias et au Lias: contrôle par subsidence thermique et variations du niveau marin. PhD, University of Geneva

Mamin M (1992) Géologie du Haut val Ferret Itlaien Master Thesis, Université de Lausanne

Manatschal G (1999) Fluid-and reaction-assisted low-angle normal faulting: evidence from rift-related brittle fault rocks in the Alps (Err Nappe, eastern Switzerland) Journal of Structural Geology 21:777-793

Manatschal G, Engström A, Desmurs L, Schaltegger U, Cosca M, Müntener O, Bernoulli D (2006) What is the tectono-metamorphic evolution of continental break-up: the example of the Tasna Ocean-Continent Transition Journal of Structural Geology 28:1849-1869 doi:10.1016/j.jsg.2006.07.014

Manatschal G, Marquer D, Früh-Green GL (2000) Channelized fluid flow and mass transfer along a riftrelated detachment fault (Eastern Alps, southeast Switzerland) Geological Society of America Bulletin 112:21-33

Manatschal G, Müntener O (2009) A type sequence across an ancient magma-poor ocean-continent transition: the example of the western Alpine Tethys ophiolites Tectonophysics 473:4-19

Marshall D, Kirschner D, Bussy F (1997) A Variscan pressure-temperature-time path for the NE Mont Blanc massif Contributions to Mineralogy and Petrology 126:416-428

Masini E, Manatschal G, Mohn G (2013) The Alpine Tethys rifted margins: Reconciling old and new ideas to understand the stratigraphic architecture of magma-poor rifted margins Sedimentology 60:174-196 doi:10.1111/sed.12017

Masini E, Manatschal G, Mohn G, Unternehr P (2012) Anatomy and tectono-sedimentary evolution of a rift-related detachment system: The example of the Err detachment (central Alps, SE Switzerland) Geological Society of America Bulletin 124:1535-1551 doi:10.1130/B30557.1

Masson H, Herb R, Steck A (1980) Helvetic Alps of Western Switzerland. Geology of Switzerland Wepf and Company, Basel

McMahon S, van Smeerdijk Hood A, Mcllroy D (2017) The origin and occurrence of subaqueous sedimentary cracks Geological Society, London, Special Publications 448:285-309 
Meyer S (2002) Etude géologique de la couverture mésozoïque para-autochtone du Mont-Blanc et des unités helvétiques au sud-ouest du Montt-Blanc. Master, Université de Lausanne

Mohn G, Karner GD, Manatschal G, Johnson CA (2015) Structural and stratigraphic evolution of the Iberia-Newfoundland hyper-extended rifted margin: a quantitative modelling approach Geological Society, London, Special Publications 413:53-89 doi:10.1144/SP413.9

Mohn G, Manatschal G, Beltrando M, Haupert I (2014) The role of rift-inherited hyper-extension in Alpine-type orogens Terra Nova 26:347-353 doi:10.1111/ter.12104

Mohn G, Manatschal G, Beltrando M, Masini E, Kusznir N (2012) Necking of continental crust in magmapoor rifted margins: Evidence from the fossil Alpine Tethys margins Tectonics 31:TC1012

Mohn G, Manatschal G, Masini E, Müntener O (2011) Rift-related inheritance in orogens: a case study from the Austroalpine nappes in Central Alps (SE-Switzerland and N-Italy) International Journal of Earth Sciences 100:937-961 doi:10.1007/s00531-010-0630-2

Olariu C, Steel RJ, Dalrymple RW, Gingras MK (2012) Tidal dunes versus tidal bars: The sedimentological and architectural characteristics of compound dunes in a tidal seaway, the lower Baronia Sandstone (Lower Eocene), Ager Basin, Spain Sedimentary Geology 279:134-155

Osmundsen P, Ebbing J (2008) Styles of extension offshore mid-Norway and implications for mechanisms of crustal thinning at passive margins Tectonics 27

Osmundsen P, Péron-Pinvidic G (2018) Crustal-Scale Fault Interaction at Rifted Margins and the Formation of Domain-Bounding Breakaway Complexes: Insights From Offshore Norway Tectonics 37:935-964

Paton C, Hellstrom J, Paul B, Woodhead J, Hergt J (2011) lolite: Freeware for the visualisation and processing of mass spectrometric data Journal of Analytical Atomic Spectrometry 26:25082518

Peron-Pinvidic G, Manatschal G, Osmundsen PT (2013) Structural comparison of archetypal Atlantic rifted margins: A review of observations and concepts Marine and Petroleum Geology 43:2147

Peron-Pinvidic G, Naliboff J (2020) The exhumation detachment factory Geology

Petrus JA, Kamber BS (2012) VizualAge: A novel approach to laser ablation ICP-MS U-Pb geochronology data reduction Geostandards and Geoanalytical Research 36:247-270

Pettijohn FJ, Potter PE, Siever R (2012) Sand and sandstone. Springer Science \& Business Media,

Pfiffner A (2011) Explanatory Notes to the Structural Map of he Helvetic Zone of the Swiss Alps, including Vorarlberg (Austria) and Haute Savoie (France) vol 2011. swisstopo,

Pfiffner O-A (1993) The structure of the Helvetic nappes and its relation to the mechanical stratigraphy Journal of Structural Geology 15:511-511

Pfiffner O-A, Burkhard M, Hänni R, Kammer A, Kligfield R, Mancktelow N, Menkveld J, Ramsay J, Schmid S, Zurbriggen R (2010) Structural map of the Helvetic zone of the Swiss Alps, including Vorarlberg (Austria) and Haute Savoie (France). Swiss Geological Survey, swisstopo,

Pik R, Bellahsen N, Leroy S, Denèle Y, Razin P, Ahmed A, Khanbari K (2013) Structural control of basement denudation during rifting revealed by low-temperature (U-Th-Sm)/He thermochronology of the Socotra Island basement-Southern Gulf of Aden margin Tectonophysics 607:17-31

Platt JP, Behr WM, Cooper FJ (2015) Metamorphic core complexes: windows into the mechanics and rheology of the crust Journal of the Geological Society 172:9-27

Principi G, Bortolotti V, Chiari M, Cortesogno L, Gaggero L, Marcucci M, Saccani E, Treves B (2004) The pre-orogenic volcano-sedimentary covers of the Western Tethys oceanic basin: a review Ofioliti 29:177-211

Reynaud J-Y, Dalrymple RW (2012) Shallow-marine tidal deposits. In: Principles of Tidal Sedimentology. Springer, pp 335-369

Ribes C, Ghienne J-F, Manatschal G, Decarlis A, Karner GD, Figueredo PH, Johnson CA (2019a) Longlived mega fault-scarps and related breccias at distal rifted margins: Insights from continental rifted margin and fossil analogues Journal of the Geological Society doi:10.1144/jgs2018.181 
Ribes C, Manatschal G, Ghienne J-F, Karner GD, Johnson CA, Figueredo PH, Incerpi N, Epin M-E (2019b) The syn-rift stratigraphic record across a fossil hyper-extended rifted margin: The example of the northwestern Adriatic margin exposed in the Central Alps International Journal of Earth Sciences:1-25 doi:10.1007/s00531-019-01750-6

Ribes C, Petri B, Ghienne J-F, Manatschal G, Galster F, Karner GD, Figueredo PH, Johnson CA, Karpoff A-M (2019c) Tectono-sedimentary evolution of a fossil ocean-continent transition: Tasna nappe, central Alps (SE Switzerland) Geological Society of America Bulletin doi:10.1130/B35310.1

Ritter E (1897) La bordure sud-ouest du Mont-Blanc: les plis couchés du Mont-Joly et de ses attaches Bulletin Service Carte géologique France 9:1-232

Schmid S, Kissling E (2000) The arc of the western Alps in the light of geophysical data on deep crustal structure Tectonics 19:62-85

Schmid SM, Fügenschuh B, Kissling E, Schuster R (2004) Tectonic map and overall architecture of the Alpine orogen Eclogae Geologicae Helvetiae 97:93-117 doi:10.1007/s00015-004-1113-x

Schmid SM, Kissling E, Diehl T, van Hinsbergen DJ, Molli G (2017) Ivrea mantle wedge, arc of the Western Alps, and kinematic evolution of the Alps-Apennines orogenic system Swiss Journal of Geosciences 110:581-612

Scholz CH (1987) Wear and gouge formation in brittle faulting Geology 15:493-495

Sharp IR, Gawthorpe RL, Underhill JR, Gupta S (2000) Fault-propagation folding in extensional settings: Examples of structural style and synrift sedimentary response from the Suez rift, Sinai, Egypt Geological Society of America Bulletin 112:1877-1899

Spencer JE (1984) Role of tectonic denudation in warping and uplift of low-angle normal faults Geology 12:95-98

Stampfli G, Borel GD, Marchant R, Mosar J (2002) Western Alps geological constraints on western Tethyan reconstructions Journal of the Virtual Explorer 8:77

Steck A, Bigioggero B, Dal Piaz G, Escher A, Martinotti G, Masson H (1999) Carte tectonique des Alpes de Suisse occidentale et des régions avoisinantes 1: 100000 Carte géologique spéciale 123

Steck A, Epard J-L, Escher A, Marchant R, Masson H, Spring L (1989) Coupe tectonique horizontale des Alpes centrales. vol 5 . Institut de géologie et paléontologie,

Steck A, Epard J, Escher A, Gouffon Y, Masson H (2001) Notice explicative pour la carte tectonique des Alpes de Suisse occidentale Wabern: Swisstopo

Stockmal GS, Beaumont C (1987) Geodynamic models of convergent margin tectonics: the southern Canadian Cordillera and the Swiss Alps

Sutra E, Manatschal G (2012) How does the continental crust thin in a hyperextended rifted margin? Insights from the Iberia margin Geology 40:139-142 doi:10.1130/G32786.1

Symonds PA, Parums R, Hill G, Hirst B, Bernardel G, Stagg H (2001) The Outer Limits of Australia's Resource Jurisdiction Off Eastern Australia

Talbot CJ, Ghebreab W (1997) Red Sea detachment and basement core complexes in Eritrea Geology 25:655-658

Talling PJ, Masson DG, Sumner EJ, Malgesini G (2012) Subaqueous sediment density flows: Depositional processes and deposit types Sedimentology 59:1937-2003

Tanner P (1998) Interstratal dewatering origin for polygonal patterns of sand-filled cracks: a case study from late Proterozoic metasediments of Islay, Scotland Sedimentology 45:71-89

Thouvenot F, Senechal G, Truffert C, Guellec S (1996) Comparison between two techniques of linedrawing migration (ray-tracing and common tangent method) MEMOIRES-SOCIETE GEOLOGIQUE DE FRANCE:53-60

Totterdell J, Blevin J, Struckmeyer H, Bradshaw B, Colwell J, Kennard J (2000) A NEW SEQUENCE FRAMEWORK FORTHE GREAT AUSTRALIAN BIGHT: STARTING WITH A CLEAN SLATE The APPEA Journal 40:95-118

Triboulet S (1980) Etude geologique entre Belledonne et Mont Blanc: la terminaison septentrionale du massif de Belledonne et les terrains de son enveloppe-Alpes françaises. PhD, Université Pierre et Marie Curie de Paris 
Trumpy R (1963) Sur les racines des nappes helvetiques. Livre a la Memoire du Professeur Paul Fallot, 2, 419-29 Soc Geol France

Trümpy R (1951) Sur les racines helvétique et les" Schistes lustrés" entre le Rhône et la Vallée de Bagnes (Région de la Pierre Avoi). Birkhäuser,

Trümpy R (1954) La zone de Sion-Courmayeur dans le haut Val Ferret valaisan Eclogae Geol Helv 47:315-359

Trümpy R (1971) Sur le Jurassique de la zone Helvétique en Suisse.

Trümpy R (1980) Geology of Switzerland: a guide-book. Schweiz- erische Geologische Kommission. Wepf \& Co. Publishers, Basel

Tugend J, Manatschal G, Kusznir N, Masini E (2015) Characterizing and identifying structural domains at rifted continental margins: application to the Bay of Biscay margins and its Western Pyrenean fossil remnants Geological Society, London, Special Publications 413:171-203

Unternehr P, Péron-Pinvidic G, Manatschal G, Sutra E (2010) Hyper-extended crust in the South Atlantic: in search of a model

Veevers J (2012) Reconstructions before rifting and drifting reveal the geological connections between Antarctica and its conjugates in Gondwanaland Earth-Science Reviews 111:249-318

Von Raumer J, Ménot R, Abrecht J, Biino G (1993) The Pre-Alpine evolution of the External massifs. In: Pre-mesozoic geology in the Alps. Springer, pp 221-240

Von Raumer JF, Bussy F (2004) Mont Blanc and Aiguilles Rouges geology of their polymetamorphic basement (external massifs, Westerns Alps, France-Switzerland). In: Mémoires de Géologie (Lausanne), vol 42. pp 1-210

Von Raumer JF, Bussy F, Schaltegger U, Schulz B, Stampfli GM (2013) Pre-Mesozoic Alpine basementstheir place in the European Paleozoic framework Bulletin 125:89-108

Webber S (2017) Using Structural Geology and Cosmogenic Nuclide Dating to Infer the Slip Rate and Frictional Strength of the Active Mai'iu Low-Angle Normal Fault, Eastern Papua New Guinea. Master Thesis, Victoria University of Wellington

Wernicke B (1985) Uniform-sense normal simple shear of the continental lithosphere Canadian Journal of Earth Sciences 22:108-125 doi:10.1139/e85-009

Wernicke B, Axen GJ (1988) On the role of isostasy in the evolution of normal fault systems Geology 16:848-851

Whitney DL, Teyssier C, Rey P, Buck WR (2013) Continental and oceanic core complexes Bulletin 125:273-298

Wibberley C (1999) Are feldspar-to-mica reactions necessarily reaction-softening processes in fault zones? Journal of Structural Geology 21:1219-1227

Wiedenbeck M, Alle P, Corfu F, Griffin W, Meier M, Oberli F, Quadt Av, Roddick J, Spiegel W (1995) Three natural zircon standards for U-Th-Pb, Lu-Hf, trace element and REE analyses Geostandards newsletter 19:1-23

Wildi W, Funk H, Loup BFR, Amato E, Huggenberger P (1989) Mesozoic subsidence history of the European marginal shelves of the alpine Tethys (Helvetic realm, Swiss Plateau and Jura) Eclogae Geologicae Helvetiae 82:817-840

Wizevich MC, Ahern J, Meyer CA (2019) The Triassic of southwestern Switzerland-Marine or nonmarine, that is the question! Palaeogeography, Palaeoclimatology, Palaeoecology 514:577592 
Figure 1 (A) Simplified paleogeographic map of the Alps from Mohn et al. (2014). The European external zone extends from the little-deformed Jura Mountains, across the foreland Molasse basin and the fold-and-thrust belt of the Dauphinois nappes to the External Crystalline Massifs including the Mont Blanc massif. The European external zone is separated from the internal zone by the Penninic Front (P.F). The internal zone is bounded by the P.F to the WNW and by the Periadriatic Line (including the Insubric) to the ESE. (B) Depth migration of the ECORS-CROP profile from Mohn et al. (2014) modified after Thouvenot et al. (1996). (C) published interpretation of the ECORS-CROP profile by Mohn et al. (2014) as a 'rift inheritance model', which combines observations of surface geology with the geometry of present-day rifted margins. (D) Palaeo-cross-section across the Alpine Tethys margins at the end of rifting and before onset of Alpine convergence in Late Cretaceous times. Redrawn from Mohn et al. (2011), no scale intended. For location of cross section see (A). ECM: External Crystalline Massifs; Aa: Aar massif; Ar: Argenteras massif; Be: Belledone; CB: Cusio Biellese; CG: Campo-Grosina nappes; MB: Mont Blanc massif; Pe: Pelvoux; H-E: hyper-extended.

Figure 2 (A) Tectonic map compiled from Burkhard (1988), Steck et al. (1989), and Leloup et al. (2005), green stars are sample locations for detrital zircon. CR-MB-1A Top Grès Singuliers, coordinates: $46^{\circ} 03^{\prime} 23.41^{\prime \prime} \mathrm{N}, 7^{\circ} 07^{\prime} 47.62^{\prime \prime} \mathrm{E}$; CR-MB-1B base Grès Singuliers unit, coordinates: $46^{\circ} 03^{\prime} 47.06^{\prime \prime} \mathrm{N}$, $7^{\circ} 07^{\prime} 11.67^{\prime \prime} \mathrm{E}, \mathrm{EC} 16$ base Grès Singuliers unit, coordinates: $45^{\circ} 43^{\prime} 55.30^{\prime \prime} \mathrm{N}, 6^{\circ} 43^{\prime} 27.86^{\prime \prime} \mathrm{E}$ and EC17 top Grès Singuliers unit, coordinates: $45^{\circ} 43^{\prime} 52.87^{\prime \prime} \mathrm{N}, 6^{\circ} 43^{\prime} 25.28^{\prime \prime} \mathrm{E}$; EC20 Triassic quartzite, coordinates: $45^{\circ} 43^{\prime} 47.17^{\prime \prime} \mathrm{N}, 6^{\circ} 43^{\prime} 54.31^{\prime \prime} \mathrm{E}$; EC23 Permo-Triassic, coordinates: $45^{\circ} 41^{\prime} 39^{\prime \prime} \mathrm{N}, 6^{\circ} 43^{\prime} 20 .{ }^{\prime \prime} \mathrm{E}$. S-C: SionCourmayeur nappe. (B) Geological section through the Helvetic basement and cover nappes in the Mont Blanc region, redrawn from Escher (1993). (C) Palinspastic map of the Helvetic domain of western 
1272 (2011). (D) Late Jurassic Palinspastic reconstruction of the Mont Blanc and Aiguilles-Rouges basement 1273 massifs and of Helvetic nappes redrawn from Lemoine \& Trümpy (1987).

Figure 3 Schematic stratigraphic succession of the dauphinois realm based on literature compilation 1276 (Trümpy 1980; Epard 1989; Pfiffner 2011) and own observations. The four tectonic System Tracts (ST)

1277 including stretching, necking, hyper-extension and mantle exhumation are derived from Ribes (2019b).

1278 H. siliciclastic "Helvetic facies", D. marly "Dauphinois facies". The Triassic pre-rift is around 20-30m 1279 thick, the syn-rift sediments show large variations in thickness but is around 500m thick.

Figure 4 (A) Panoramic view of the Col des Fours with the Penninic Front (PF) in the south, the Diableret Thrust (DT) and the autochthonous sedimentary cover of the Mont Blanc massif, location indicated on (B). Distance between Tête Nord des Fours and Tête Sud des Fours: 700m. (B) Geological map of Bonhomme area, southern border of the Mont Blanc massif, modified from (Meyer 2002). Green stars correspond to the location of the Grès Singuliers unit samples (samples EC16 and EC17) and Triassic quartzite sample (EC20). Location of Fig 3b shown on Fig 2. (C) Geological map of the Swiss Val Ferret, northeastern part of the Mont Blanc massif, based on data compiled from (Grasmück 1961) and (Steck et al. 1989). Black squares correspond to the location of the Grès Singuliers unit samples in Catogne area (samples CR-MB-1B and CR-MB-1A).

Figure 5 Fabrics and structures of the damage zone of the Mont Blanc detachment system. (A) 1292 panoramic view of the l'Amône outcrop with the Mont Blanc detachment system. Location of B and C 1293 indicated. (B) Cataclastic fabric overprinting the porphyritic granitic basement and black gouge 1294 including sub-angular basement clasts, picture from l'Amône outcrop (World Geodetic System 1984 [WGS 84] coordinates: $\left.45^{\circ} 56^{\prime} 30^{\prime \prime} \mathrm{N}, 7^{\circ} 5^{\prime} 31^{\prime \prime} \mathrm{E}\right)$. (C) Cataclastic fabric overprinting the porphyritic granitic 
basement illustrating occurrence of sub-angular to sub-rounded clasts of basement in Combe des Fonds (coordinates: $45^{\circ} 55^{\prime} 23^{\prime \prime} \mathrm{N}, 7^{\circ} 4^{\prime} 55^{\prime \prime} \mathrm{E}$ ). (D) Cataclastic fabric overprinting the Variscan metamorphic basement and black gouge underlying covered by slice of Triassic sandstone (Vieux Emosson Fm.) and dolostones (Arandellys Fm.) picture from Nant des Lotharets (coordinates: $\left.45^{\circ} 43^{\prime} 37^{\prime \prime} \mathrm{N}, 6^{\circ} 42^{\prime} 40^{\prime \prime} \mathrm{E}\right)$. (E) Black gouge with a sub-rounded clasts of Triassic dolostone, picture from Col des Fours. (F) Black gouge with quartz veins, sample from Nant des Lotharets (coordinates: $\left.45^{\circ} 44^{\prime} 11^{\prime \prime} \mathrm{N}, 6^{\circ} 43^{\prime} 46^{\prime \prime} \mathrm{E}\right)$. (G) Thin-section photomicrograph of a black gouge showing sub-rounded clasts embedded in a phyllosilicate-rich matrix with a strong preferred orientation and $S \pm C$ fabrics, Nant des Lotharets.

Figure 6 (A) Panoramic view of the autochthonous sedimentary cover of the Mont Blanc in the Bonhomme area, Tête Nord des Fours. (B and C) pictures of an extensional allochthon made up of Triassic Fms that shows different textures from monomict mosaic and crackle breccias with locally clast-supported, monomict, poorly sorted breccias with sub-angular to sub-rounded clasts. The shiny black portions are silicified matrix (Si). Pictures location indicated on Fig. 8.

Figure 7 Sedimentary log of the Grès Singuliers unit in the Bonhomme area, Tête Sud des Fours (coordinates: $45^{\circ} 43^{\prime} 55^{\prime \prime} \mathrm{N}, 6^{\circ} 43^{\prime} 16^{\prime \prime} \mathrm{E}$ ). (A) Basal conglomerate unconformably overlying the Triassic Arandellys Fm. (B) Highly amalgamated trough cross stratification. (C) Sandy high density turbidites with traction carpet at the base and ripple crest at the top. (D) Crack morphologies forming a highly connected network expressed on bedding planes with a preferential north-south orientation. (E) Sigmoidal crossbedding with thinner draped bundles that represent neap-tide and thicker sets represent spring-tide (higher tidal energy). (F) 3- to 5-meter-thick clinoforms observed at the top of the Grès Singuliers unit. (G) Thin section photomicrograph of the Grès Singuliers unit composed of 80 
to $90 \%$ of monocrystalline and polycrystalline quartz and the rest of altered feldspar and rare crushed fine-grained grains.

Figure 8 Stratigraphic correlation within the sedimentary autochthonous of the southern Mont Blanc massif, Bonhomme area. This panel summarizes the main variations in thickness, the angular unconformity at the base of the Grès Singuliers unit, and the thin-skinned deformation observed in the underlying Fms (Middle Triassic to Lower Jurassic Fms). The measured sections are located in Fig.3B. Samples for detrital zircon analyses are from the Col des Fours section. Stars represent biostratigraphic references: 1, (Eltchaninoff-Lancelot 1980); 2, (Landry 1976); 3, (Landry 1976; Eltchaninoff-Lancelot 1980); 4, (Landry 1976).

Figure 9 Stratigraphic correlation within the sedimentary autochthonous cover of the north-eastern Mont Blanc massif, Swiss Val Ferret area based on the compilation of Grasmück (1961), Loup (1991) and own observations. This panel summarizes the main variations in thickness, the angular unconformity at the base of the Grès Singuliers unit, and the thin-skinned deformation observed in the underlying Fms (Middle Triassic to Lower Jurassic Fms). The measured sections are located in Fig.3C. Samples for detrital zircon analyses are from the Catogne section, CR-MB-1A and -1B. Stars represent biostratigraphic constraints references: 1, 2, 3, 4, 5, 6, 7 (Grasmück 1961); 4, (Trümpy 1951).

Figure 10 Detrital zircon U-Pb LA-ICP-MS age distributions measured in Triassic Vieux Emosson Fm sandstones and Grès Singuliers unit. Detrital zircons 206Pb/238U age histograms and relative probability curves (grey). 
1343 Figure 11 (A) Reconstruction of the Helvetic margin during the Late Jurassic modified from Stampfli et

1344 al. (2002). See text for discussion. Bo, Bonhomme area ; Di, Diablerets nappe domain; Cb, Chamonix

1345 basin; M-C, Mont Chetif basement ; Mte L, Monte Leone nappe; S-C, zone Sion-Courmayeur; VF, Val

1346 ferret ; Wi, Wildhorn nappe domain. (B) Three-dimensional paleogeographic-tectono-stratigraphic 1347 diagrams of the late Early Jurassic illustrating sedimentary pattern of the Grès Singuliers unit in the 1348 Helvetic domain. Bo, Bonhomme area; Am, Amône; Ca, Catogne; Sa, Saillon; Ar, Ardève; Fe, Ferden 1349 (Torrenthorn).

1351 Figure 12 Upper part: Location of the whole seismic line GA199-09 (Symonds et al. 2001) along the south Australian rifted margin. In thick black the location of the displayed seismic section. The green circle represents the location of the Jerboa-1 drill site. Lower part: Uninterpreted and interpreted seismic section imaging the necking domain along line GA199-09. Normal faults are shown in red; the interpreted detachment fault is shown in dashed violet. Copyright Commonwealth of Australia (Geoscience Australia). 

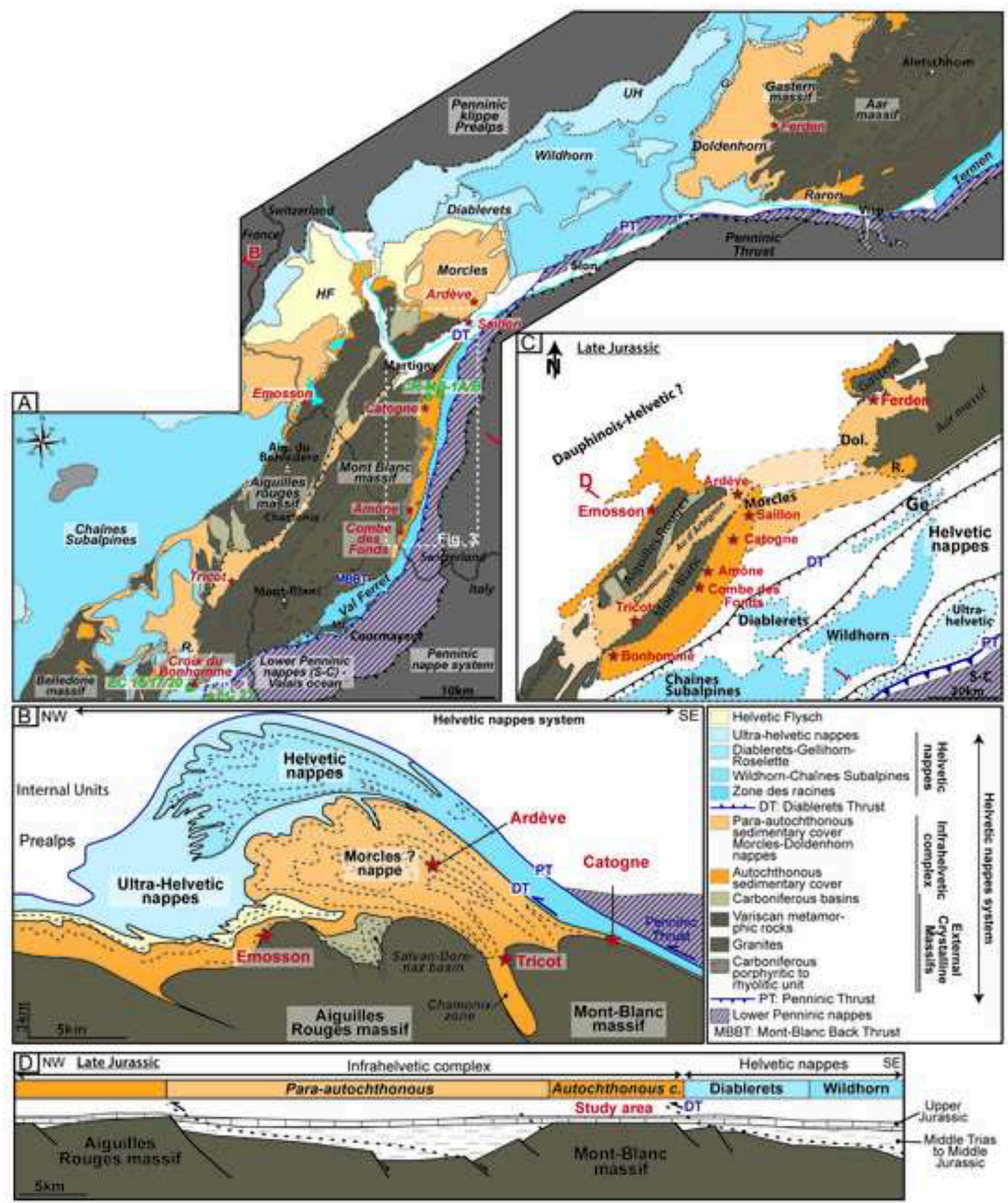


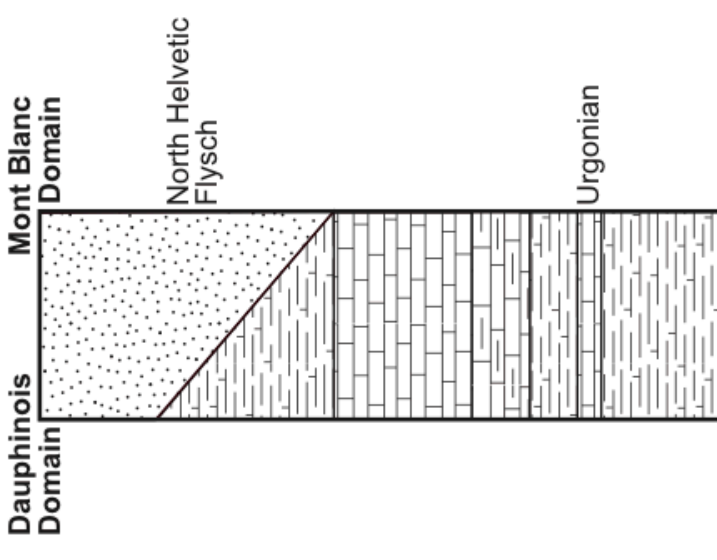

әวนวбләлиоว әи!d|

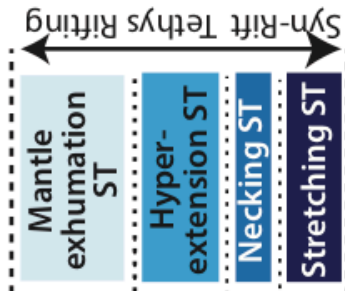

:

:

这:

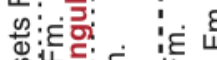

हैं

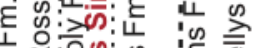

空诘:

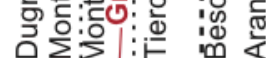

I
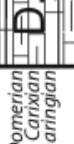

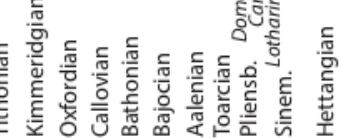

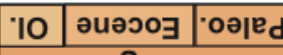

әุอา әฺеา

อุอา $\mathrm{p!W}$ әиәбоэеd sกоәэејәдว ग!ssedn 'uәболо uезs!nes ग!sseW ןеuมә]х习

हैं

(c)

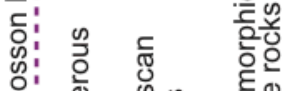

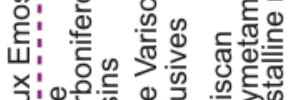
ज:

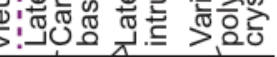



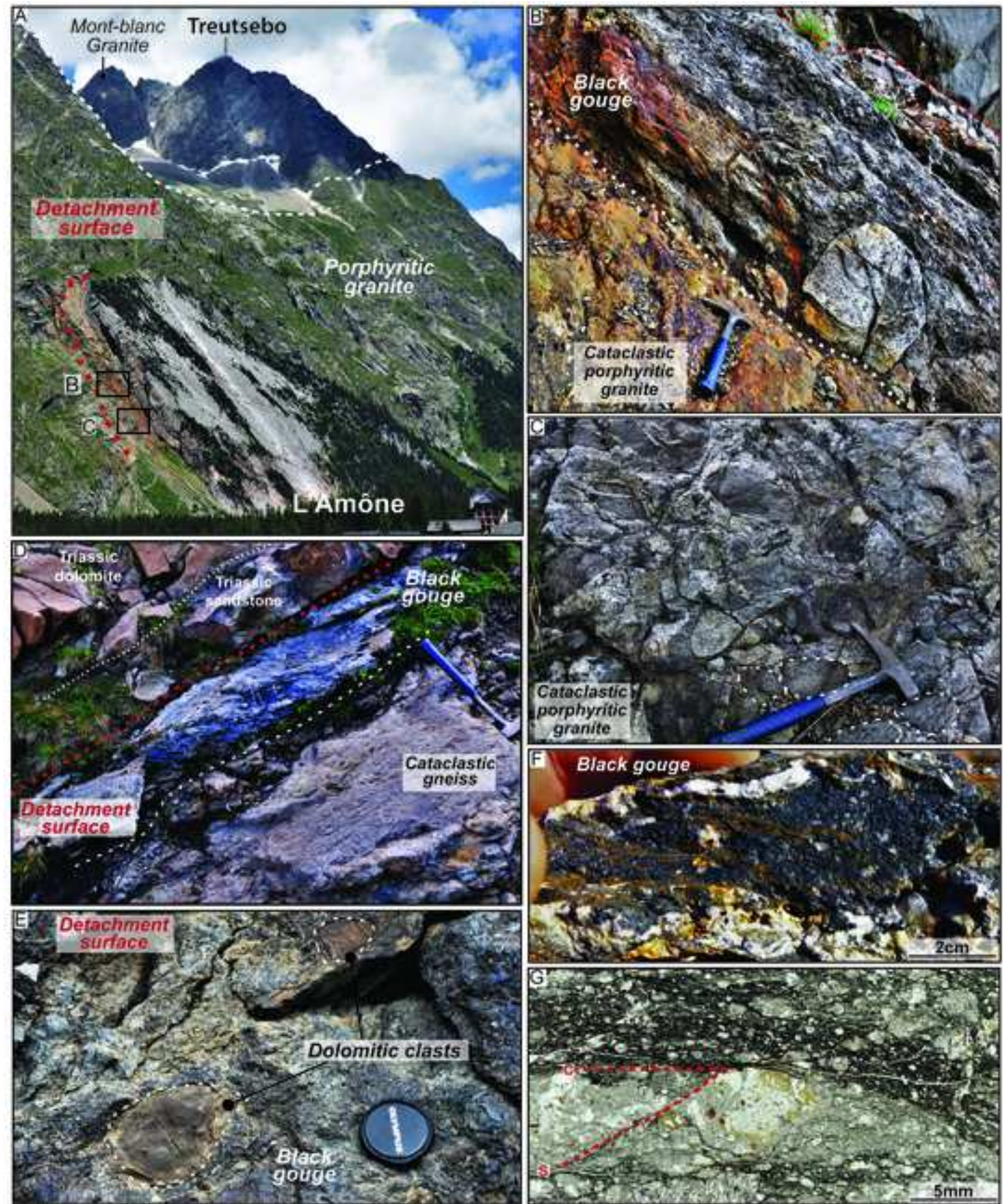


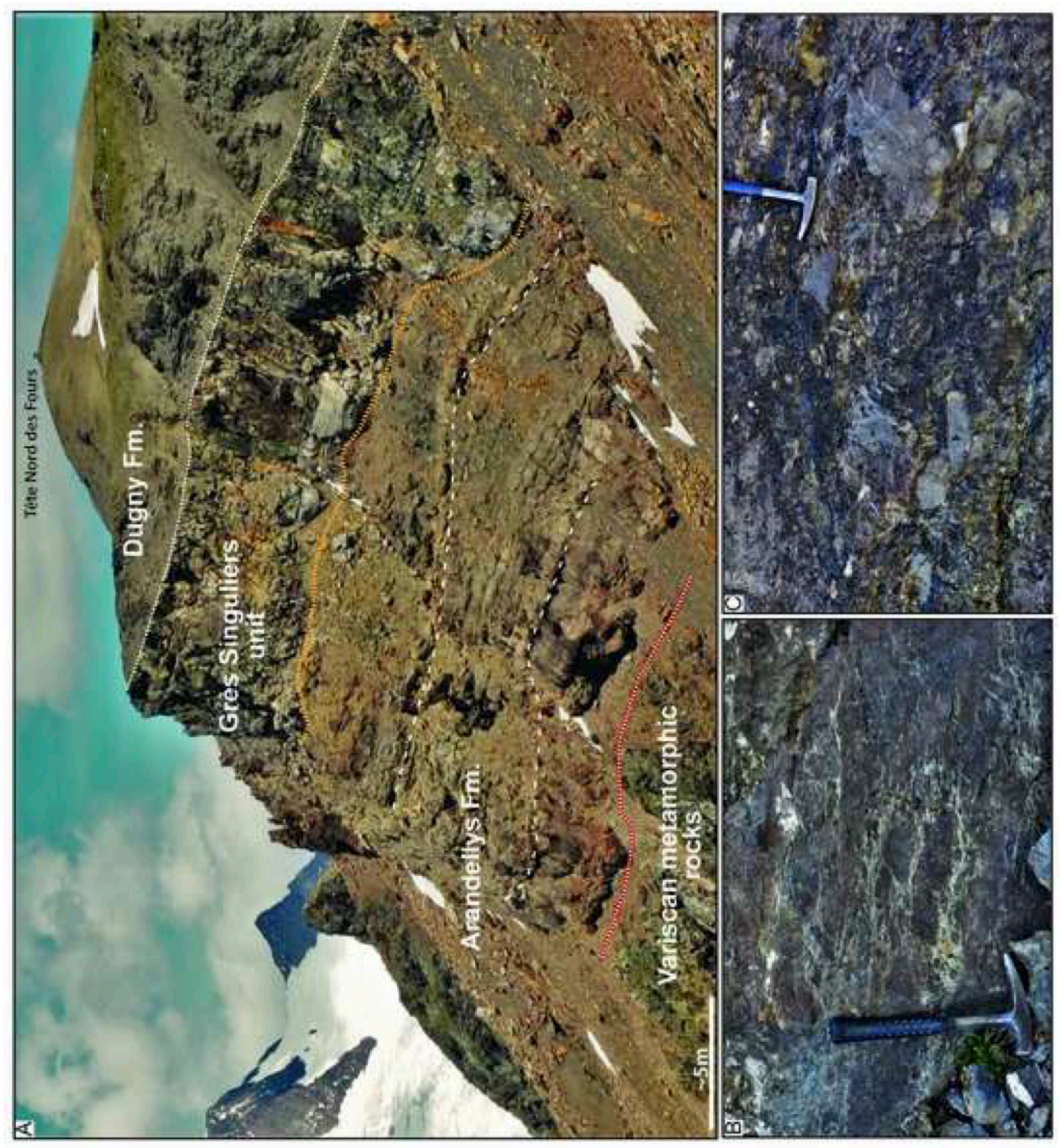



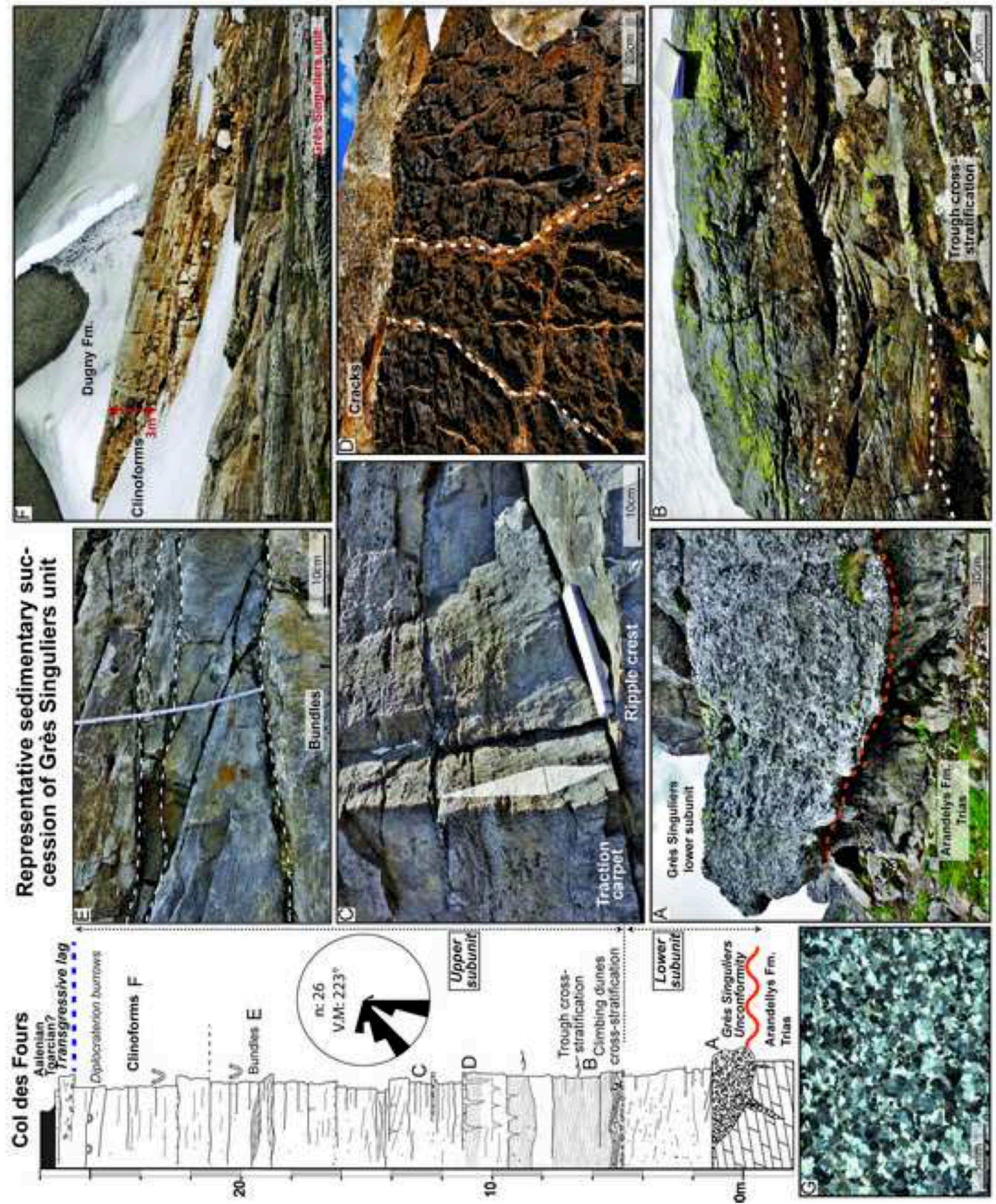


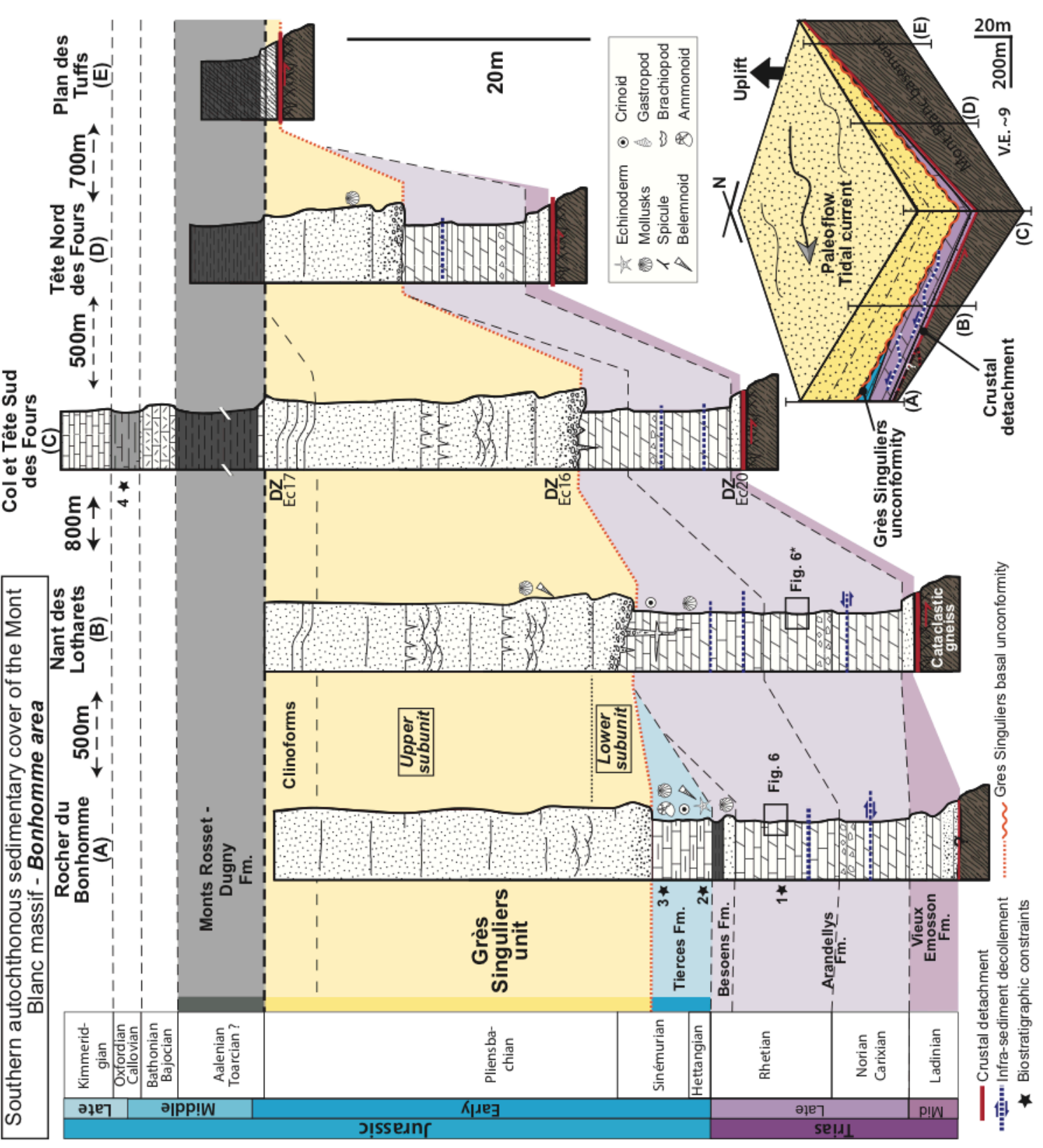

$\infty$
$\stackrel{0}{J}$
믄 


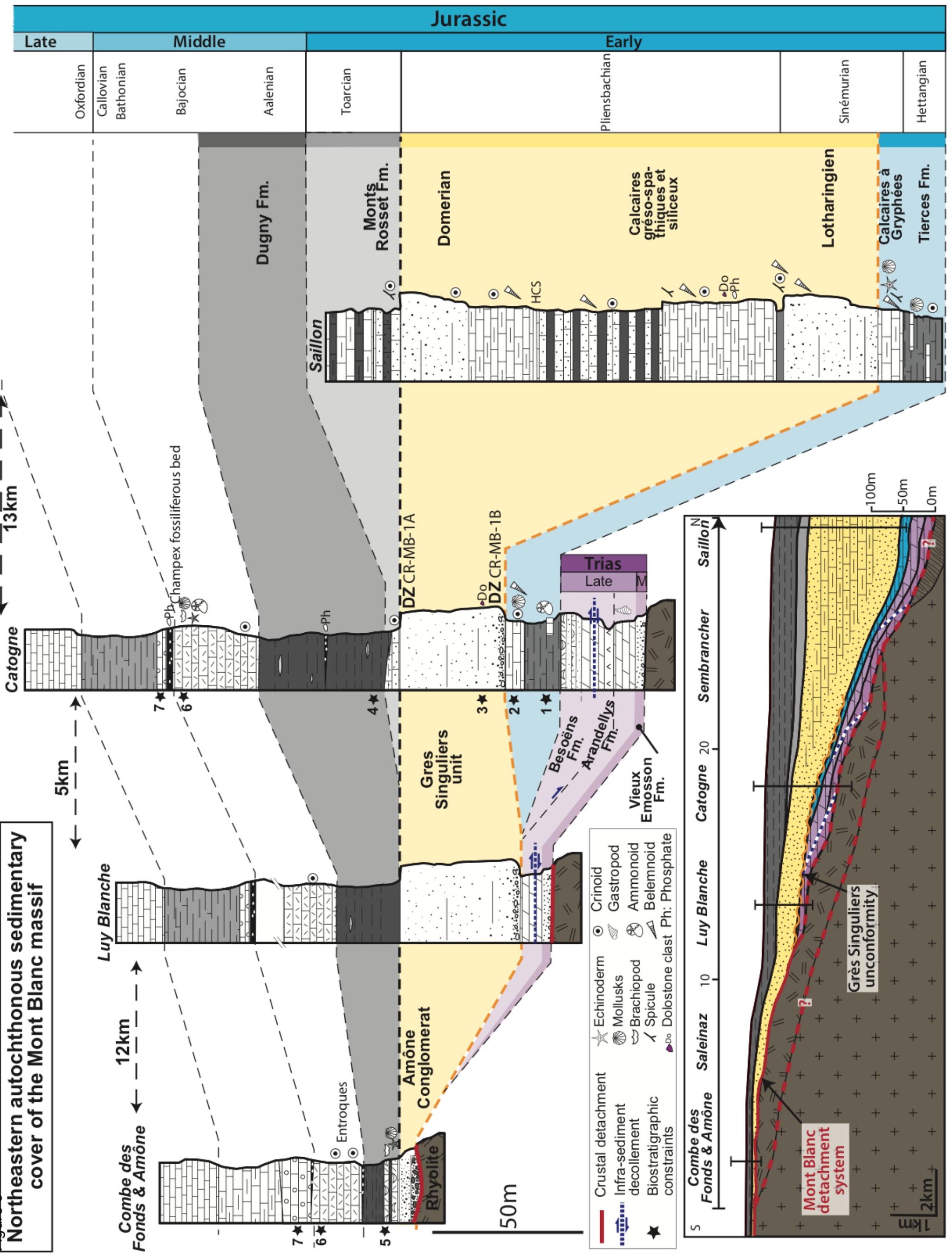


Figure $10^{15-}$

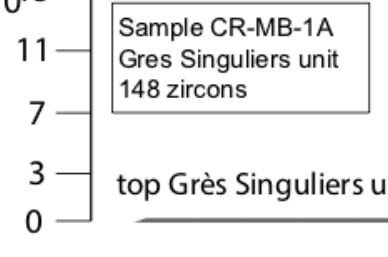

${ }^{27}$

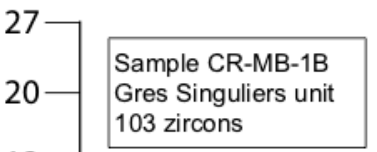

1

$$
\text { :- }
$$

ase Grès Singuliers u.

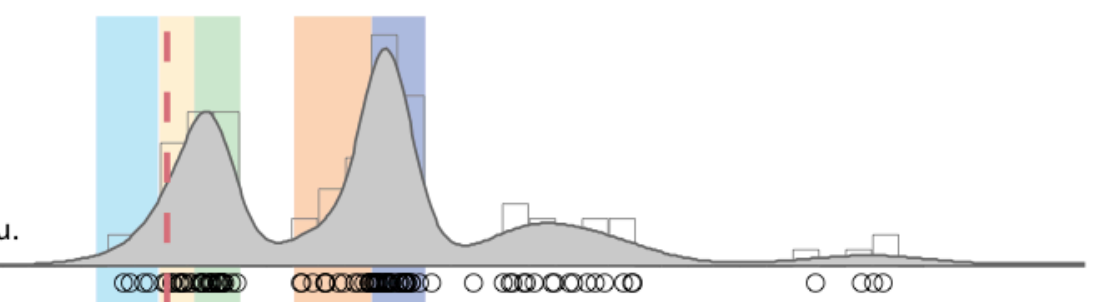

Catogne

Swiss Val Ferret -

Northeastern

Mont Blanc Massif
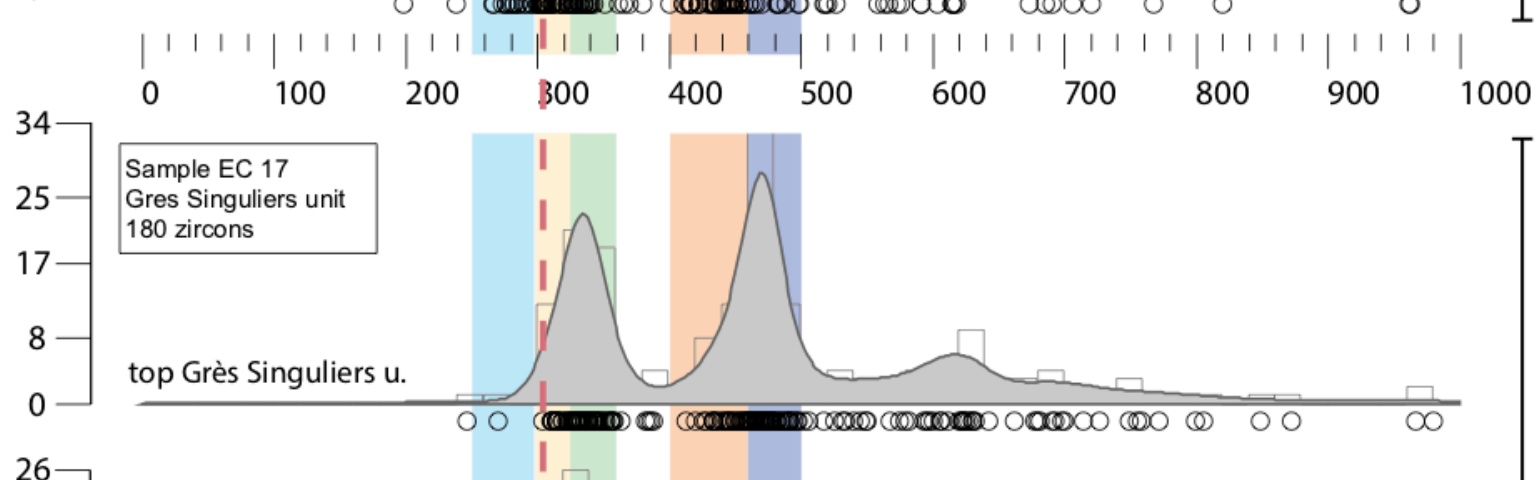

\section{$\left.\begin{array}{l}26 \\ 19 \\ 13 \\ 6 \\ 0\end{array}\right]$}

Sample EC 16

Gres Singuliers unit

151 zircons

base Grès Singuliers u.
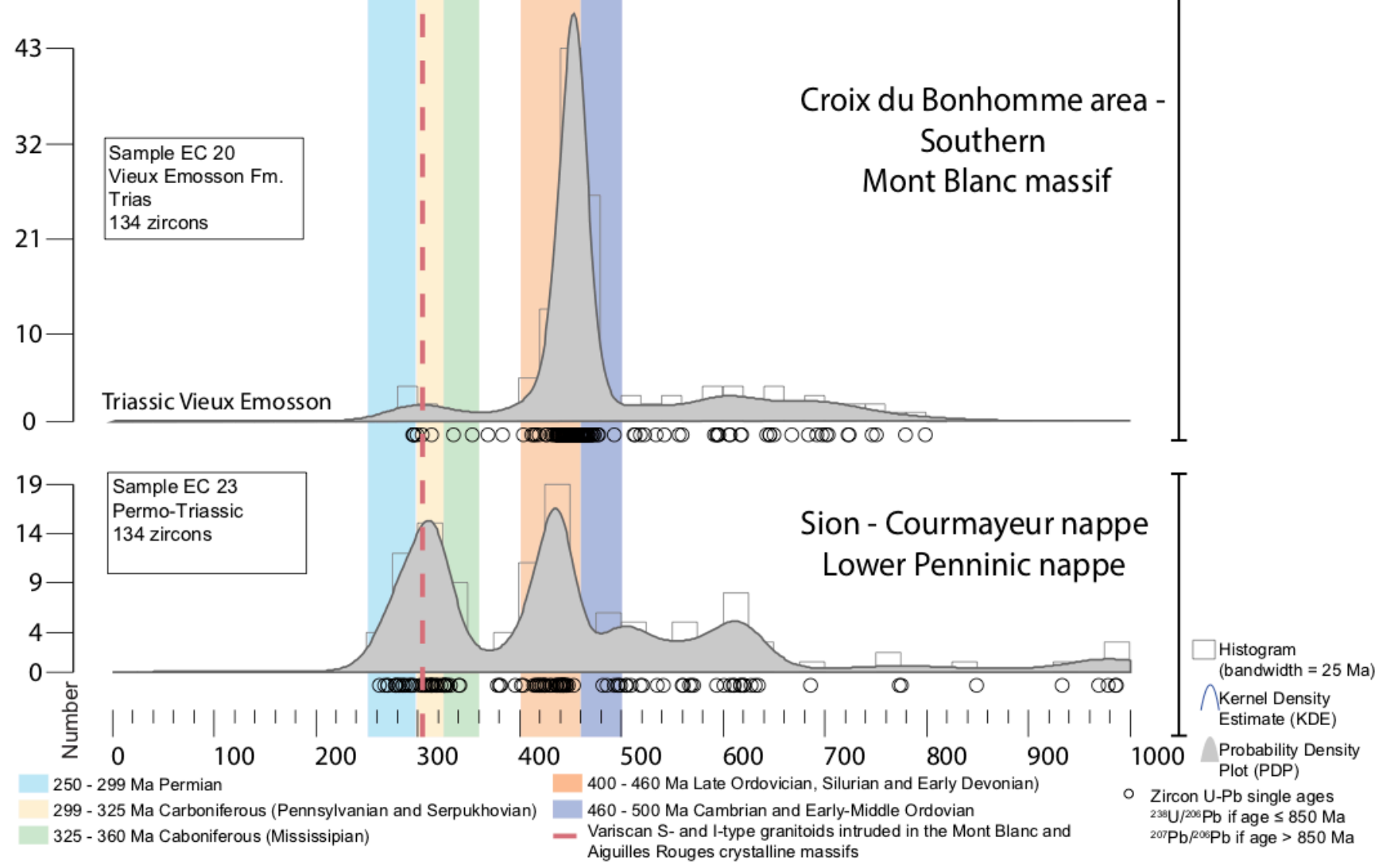


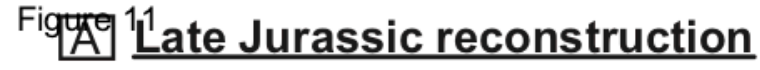

Proximal Domain

Necking D.

Hyper-extended Domain

Exhumed mantle

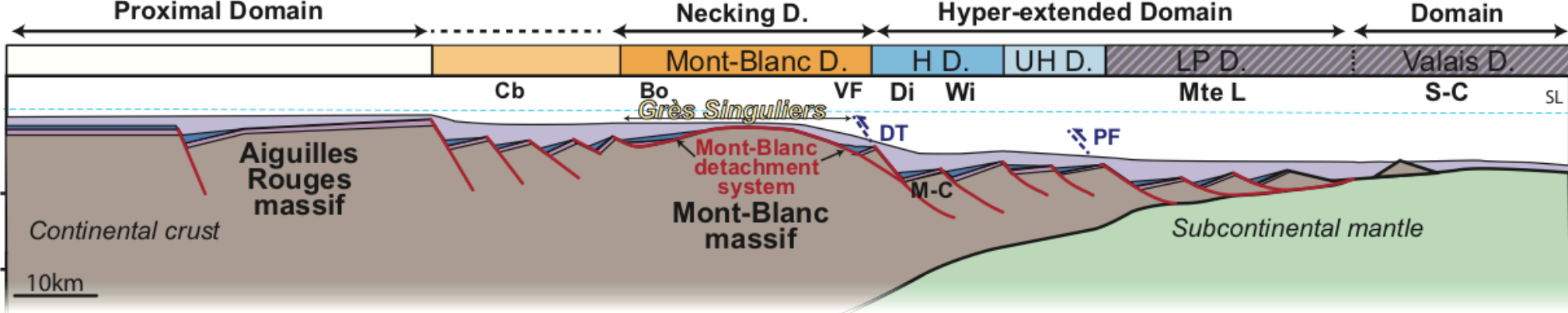

Pre-rift Trias

Lower Jurassic $\quad \square$ Middle and Late Jurassic

\section{$B$ Necking System Tract - Pliensbachian}

Grès Singuliers unit (Sandstone)

Mont Joly Fm (Limestone)

Pre-rift Trias

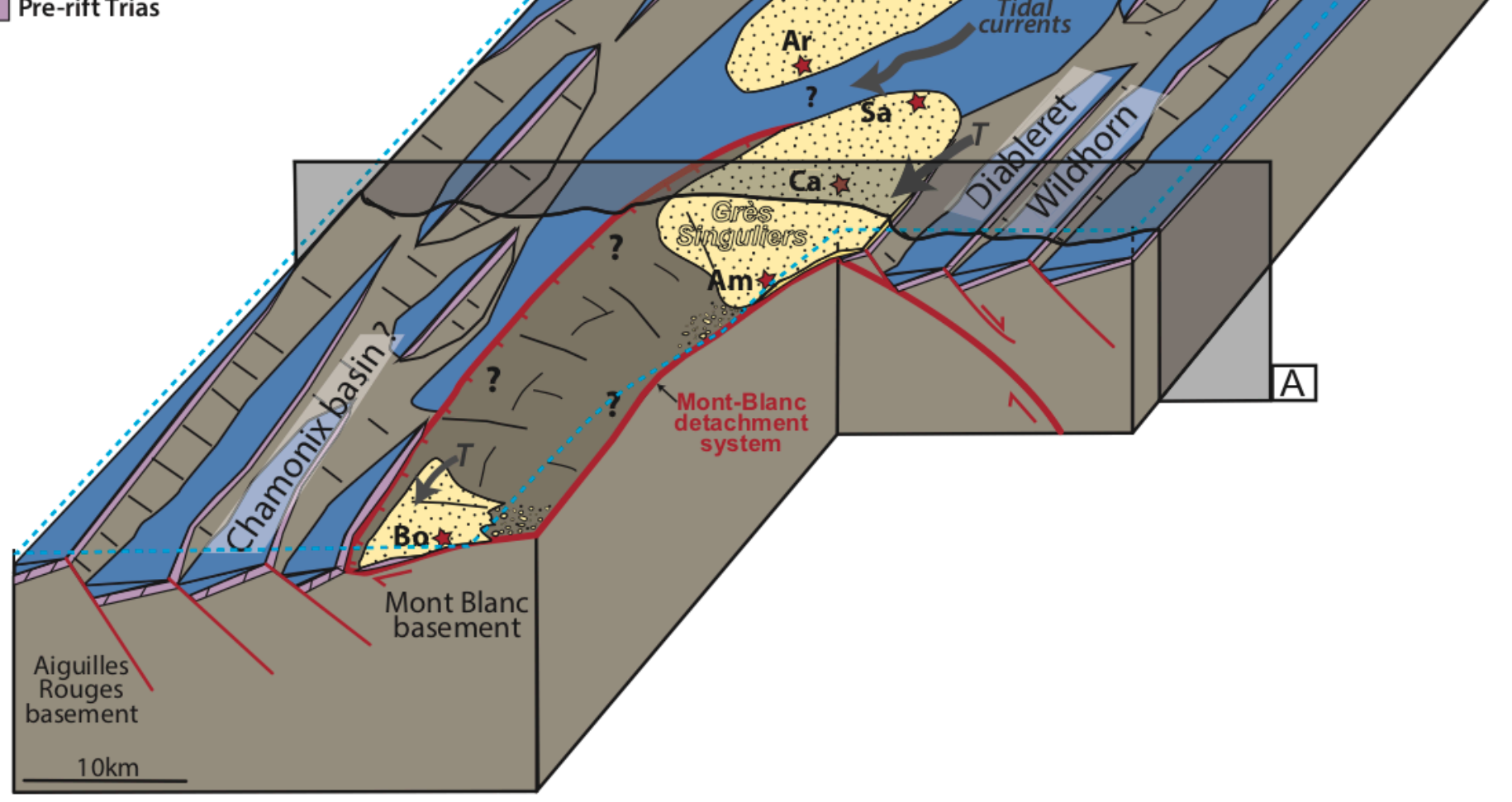



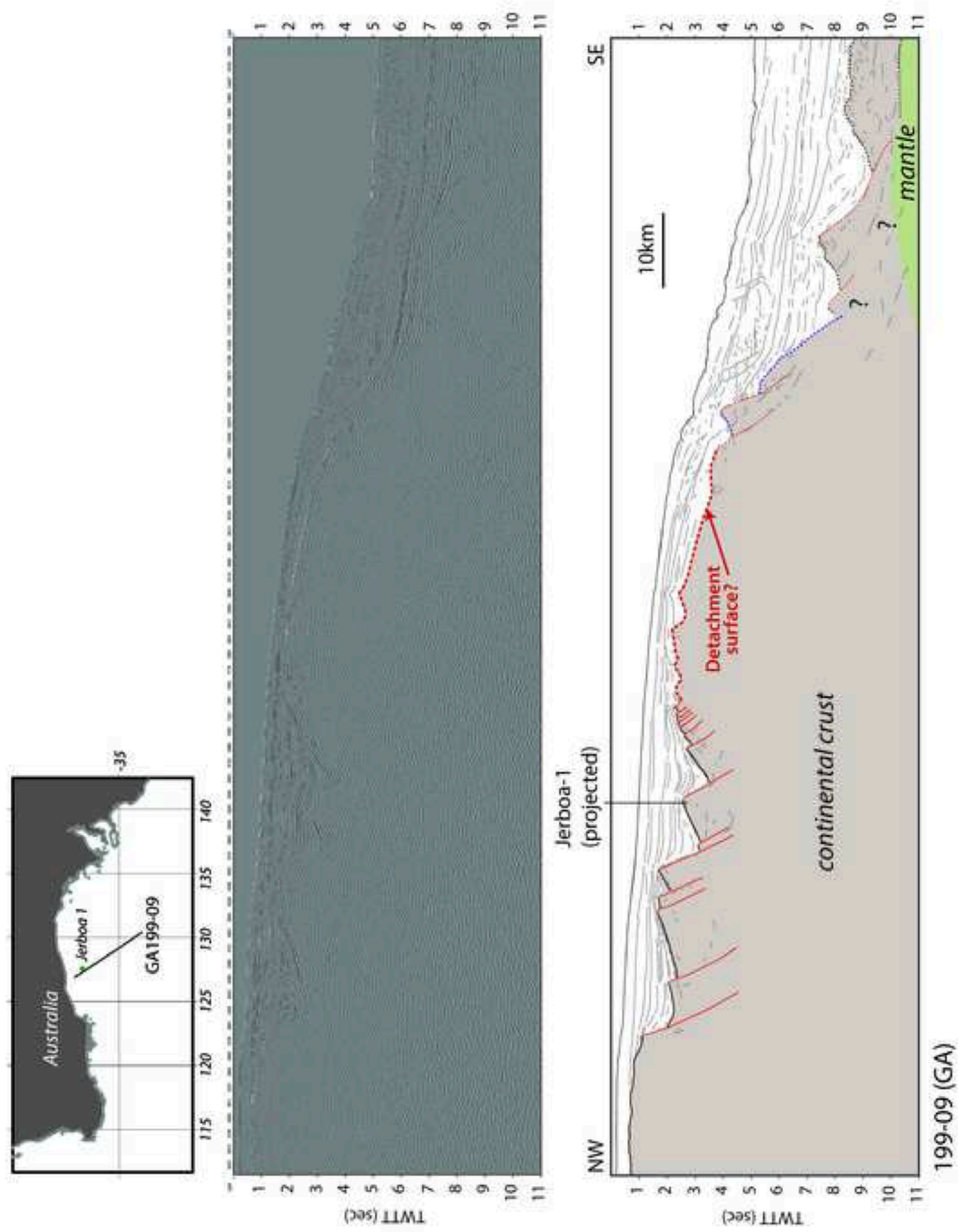